総説

\title{
内臓痛・消化器機能・消化器症状に対する鍼炎の効果
}

野口栄太郎 1） 今井 賢治 2) 角谷 英治 2) 川喜田健司 ${ }^{3}$ )

1) 筑波技術短期大学銊尒学科

2 ）明治鍼炎大学臨床鍼多医学教室

3 ) 明治鍼尒大学生理学教室

\section{The Effects of Acupuncture and Moxibustion on Visceral Pain, Digestive Function and Digestive Symptoms}

\author{
NOGUCHI Eitaro ${ }^{1}$ ) IMAI Kenji ${ }^{2)}$ SUMIYA Eiji ${ }^{2}$ ) KAWAKITA Kenji ${ }^{3}$ ) \\ 1 ) Laboratory of Acupuncture Science, Tsukuba College of Technology \\ 2 ) Department of Clinical Acupuncture and Moxibustion, Meiji University of Oriental Medicine \\ 3 ) Department of physiology, Meiji University of Oriental Medicine
}

\section{I .はじめに}

近年、銊尒の分野に扔けるEBM（根拠に基づい た医療）を求める声が世界的な規模で強くなって いる。その背景には、これまでの医療に満足でき ず、いわゆる代替医療のひとつとして鍼多を希望 する患者が急増している現状がある。そこでNIH （米国国立衛生研究所）では大規模な調査を行い 1997年11月に開催された会議をふまえ、翌年2月 には鍼に関する「米国国立衛生研究所合意形成声 明書」を発表し1,2)、これまでの基礎・臨床を含め た研究成果に基づき、いくつかの病状に対して鍼 が有効であることを明らかにした。世界の医学研 究をリードしているといえるNIHが銊の有効性に ついて報告書を書いたことは、鍼尒研究の歴史上 画期的なことである。そこで明らかにされたこと は、鍼尒の有用性を語るためには、何よりもきち んとした臨床試験が必要であるという立場であり、 症例集積ではなくランダム化比較試験といった、 よりエビデンスの強い臨床研究が求められている という事実である。それが現在のEBMを支えてい
る考え方に他ならない。

NIHの報告では我が国の鍼尒の研究成果がほと んど引用されなかったが、それは我が国において 鍼尒の研究が行われていなかったことを意味する ものではない。その理由としては、和文の研究論 文として学術雑誌に報告されていても、MEDLINE などの医学情報データベースに掲載されていない ものが多いこと、またエビデンスの強いとされる ランダム化比較試験が適切な規模で実施されて来 なかったことなどが挙げられる。

そこで本稿では、「内臟痛と消化器疾患や各種 消化器症状に対する銊尒治療」にテーマを絞り、 その研究の現状について基礎・臨床の両面から検 討を加えた。今回対象としたものは、NIHの会議 で検討された関係分野の欧文を中心とした文献と、 医学中央雑誌の和文献のデータベースや手作業に よって出来る限り網羅的に集められた研究論文で ある。我が国の研究の歴史と現状、ならびに世界 の研究の流れが表を中心にしてまとめられている ので、引用文献のリストと共に教育・研究・臨床 に役立てていただければ幸いである。 
表 1 . 使用言語

\begin{tabular}{|c|c|c|c|c|c|c|c|}
\hline & 英 語 & 中国語 & ロシア語 & ドイツ語 & イタリア語 & 日本語 & 合 計 \\
\hline \hline ヒト対象論文 & 14 & 1 & 4 & 2 & 1 & 1 & 23 \\
\hline 動物対象論文 & 4 & 9 & 1 & 0 & 0 & 0 & 14 \\
\hline 合 計 & 18 & 10 & 5 & 2 & 1 & 1 & 37 \\
\hline
\end{tabular}

表 2. ヒト対象研究

\begin{tabular}{|c|c|c|c|c|c|c|}
\hline 鍼、痛み & 腸閉塞 & 消化器系炎症性疾患 & 食道痙攣 & 潰瘍性疾患 & 内臟鎮痛 & 合 計 \\
\hline \hline 臨床論文 & 5 & 3 & 1 & 5 & 2 & 16 \\
\hline 基礎論文 & 0 & 0 & 0 & 0 & 0 & 0 \\
\hline 総説・解説 & 1 & 0 & 0 & 4 & 2 & 7 \\
\hline 合 計 & 6 & 3 & 1 & 9 & 4 & 23 \\
\hline
\end{tabular}

\section{II．内臓痛に対する鍼炎刺激の効果}

\section{1.内臓痛に対する鍼炎研究の文献}

消化器官由来の内臓痛に対する鍼尒治療（刺 激)効果に関する文献を調查するために、MEDLINE （1970－2000年）と医学中央雑誌（1987－1998年） のデータベースを用いて検索を行った。検索の際 のキーワードとしては「鍼」、「炎」に関連するも の、「内臓痛」、「胸痛」、「腹痛」等の内臟痛の起 こる部位に関するもの、「胃」、「大腸」等の消化 器官の名称、「胃潰瘍」、「膵炎」、「腸閉塞」等の 内臓痛を生じる原因疾患の名称などを用いた。そ れらの中で、查読可能な国内文献あるいは英語文 献、および英文抄録のある外国語文献を、今回の 文献調查の対象として分類した。その結果、全体 で37編の文献が検出された（MEDLINE：36編、 医学中央雑誌：0、その他：1編)。それぞれの論 文を使用言語別に分類すると、「ヒト」を対象に した23編の論文のうち、英語の論文が約61\%を占 め、「動物」を対象とした 14 編の論文では、中国 語の論文が約62\%を占めた（表 1 ）。「ヒトを対象 にした論文」では23編すべてが臨床に関連したも ので (総説・解説：7 編)、ヒトを対象にして鍼 尒刺激による内臓痛抑制のメカニズム等を扱った 基礎的な論文は見られなかった（表 2 ）。

\section{2. 臨床研究論文}

内臟痛は、日常的には、腹痛あるいは胸部痛と
いった言葉で表される。内臓痛を生じる基礎疾患 としては腸閉塞、炎症性疾患（膵炎·胆囊炎·大 腸炎など）、潰瘍性疾患（胃潰瘍・十二指腸潰瘍） などが挙げられるが、ふつう内臓痛などの症状は 原因疾患（症状）の治癒とともに消失する。しか し、内臓の慢性炎症などは簡単には治癒しないこ とも多く、内藏痛自体の管理の必要性も生じてく る。今回の検索で消化器系疾患に由来する内臓痛 を有する患者に対して鍼治療を行った臨床論文は 23編得られた。腸閉塞に関するものが 5 編、炎症 性疾患に関するものが 3 編、潰瘍性疾患に関する ものが 5 編、食道痤攣によるものが 1 編、内臟痛 に対する鍼治療に関する論文が 2 編、総説・解説 が7編あり（表 2 ）、これらのうち入手すること ができた12編の論文の内容を詳しく検討した。

1）腸閉塞よる内臓痛に対する銊治療に関する研 究 (表 3 )

Jiang $\mathrm{R}^{3)}$ は、急性腸疝痛患者190例に対して、 足三里穴を用いた鍼治療群とアトロピンの薬物 治療群の治療効果を比較したところ、銊治療群 では著効 $85 \%$ 、有効 $11 \%$ 、薬物投与群では著効 $48 \%$ 、有効 $40 \%$ となり、銊治療群は10-30秒で 効果が出始め、薬物治療群では1-4分かかったこ と報告して扔り(コホート研究)、鍼治療の有 用性を示唆している。岩ら ${ }^{4)}$ は、癒着性イレウ ス患者 3 例に対して関元穴、天枢穴、合谷穴、 足三里穴を用いた鍼治療を行ったところ、腸蠕 
表 3．腸閉塞による内臟痛

\begin{tabular}{|c|c|c|c|c|}
\hline $\begin{array}{l}\text { 著 者 } \\
\text { (発刊年) }\end{array}$ & $\begin{array}{l}\text { 対 象 } \\
\text { (例数) }\end{array}$ & $\begin{array}{l}\text { 研究デザイン } \\
\text { (比較対照) }\end{array}$ & $\begin{array}{c}\text { 治療穴 } \\
\text { (刺激方法) }\end{array}$ & 結 \\
\hline $\begin{array}{l}\text { Jiang R } \\
(1990)\end{array}$ & $\begin{array}{c}\text { 腸疝痛患者 } \\
\quad(n=190)\end{array}$ & $\begin{array}{l}\text { コホート研究 } \\
\text { (アトロピン投与群) }\end{array}$ & $\begin{array}{c}\text { 足三里 } \\
\text { (鍼刺激) }\end{array}$ & $\begin{array}{l}\text { アトロピン投与群に比べ有意に } \\
\text { 痛みが減少 }\end{array}$ \\
\hline $\begin{array}{c}\text { 岩 昌宏ら } \\
(1989)\end{array}$ & $\begin{array}{c}\text { 癒着性イレウス患者 } \\
(n=3)\end{array}$ & 症例報告 & $\begin{aligned} \text { 関元, 天枢, 合谷, 足三里 } \\
\text { (鍼刺激) }\end{aligned}$ & 腸蠕動の抑制とともに腹痛も軽減 \\
\hline $\begin{array}{l}\text { No authors listed } \\
\text { (1978) }\end{array}$ & $\begin{array}{c}\text { 急性腸閉塞患者 } \\
\qquad(n=1006)\end{array}$ & 症例集積 & $\begin{array}{l}\text { 漢方薬の補助として上脘, } \\
\text { 天枢, 足三里,内関(鍼刺激) }\end{array}$ & 71.8\%で治癒し, 腹痛が軽減 \\
\hline
\end{tabular}

表 4. 炎症性疾患による内臓痛

\begin{tabular}{|c|c|c|c|c|}
\hline $\begin{array}{l}\text { 著 者 } \\
\text { (発刊年) }\end{array}$ & $\begin{array}{l}\text { 対 象 } \\
\text { (例数) }\end{array}$ & $\begin{array}{c}\text { 研究デザイン } \\
\text { (比較対照) }\end{array}$ & $\begin{array}{c}\text { 治療穴 } \\
\text { (刺激方法) }\end{array}$ & 結 \\
\hline $\begin{array}{l}\text { Ballegaard S et al } \\
\qquad(1985)\end{array}$ & $\begin{array}{c}\text { 慢性膵炎による内臓痛患者 } \\
(\mathrm{n}=23)\end{array}$ & $\begin{array}{l}\text { ランダム化比較試験 } \\
\text { (非経穴部位, } \\
\text { 異分節部経穴) }\end{array}$ & $\begin{array}{l}\text { 1) 肝俞一胆俞の間 } \\
\text { 2) 膵俞 } \\
\text { (鍼通電, TENS) }\end{array}$ & $\begin{array}{l}\text { 膵臓と同脊髄分節の背部経穴へ } \\
\text { の鍼治療で有意に痛みが減少 }\end{array}$ \\
\hline $\begin{array}{l}\text { Zhang J } \\
\text { (1992) }\end{array}$ & $\begin{array}{c}\text { 胆軎炎·胃炎による心窩部痛患者 } \\
\qquad(n=3)\end{array}$ & 症例報告 & $\begin{array}{c}\text { 足三里 } \\
\text { (鍼刺激) }\end{array}$ & 5 ～20分後に痛みが消失 \\
\hline $\begin{array}{l}\text { Li S R et al } \\
\quad(1988)\end{array}$ & $\begin{array}{c}\text { 慢性結腸炎による反復性腹痛患者 } \\
\qquad(\mathrm{n}=61)\end{array}$ & 症例集積 & $\begin{array}{l}\text { 大腸俞, 神闒 } \\
\text { (レーザー銊) }\end{array}$ & $\begin{array}{l}\text { 慢性結腸炎の治癒と伴に腹痛も } \\
\text { 消失 }\end{array}$ \\
\hline
\end{tabular}

動の抑制とともに腹痛も軽減したことから、鍼 治療がイレウス患者への保存的療法の有用な手 段の一つであることを示唆している。また、手 術適用でない722例の急性腸閉塞患者に対して、 漢方薬治療の補助療法として上脘穴、天枢穴、 足三里穴、内関穴を用いた銊治療を施行したと ころ、便通は100\%改善し、麻痺性イレウスは $91.5 \%$ で治癒し、単純癒着性イレウスは $74.5 \%$ で治癒したという報告もある5)。

2) 炎症性疾患による内臓痛に対する鍼治療に関 する研究 (表 4 )

Ballegaard Sら 6) は、3ヶ月以上毎日痛みがあ る慢性膵炎患者に対して、瘦脈穴、耳の肺点、 公孫穴、膵臓と同分節点（肝俞穴と胆俞穴の 間）の鍼通電治療 5 回と背中を同じ分節で経穴 の外側 $3 \mathrm{~cm}$ 以内の点としたsham経穴鍼通電治 療 5 回をランダムに施行したところ $(n=11) 、$ 銊通電治療群ではsham経穴鍼治療群に比べて治 療前後のVASが有意に減少したことを報告した。 また、膵俞に経皮的通電刺激を行った際にも、
膵俞の外方の部位あるいは大杼穴に経皮的通電 刺激を行った場合に比べて有意にVASが減少し、 毎日の鎮痛剂の使用量も少なかったことを報告 しており (ランダム化比較試験)、内臟痛の鎮 痛に関しては，原因疾患臓器と同じ脊髄分節の 背部俞穴を用いた鍼治療の効果を示している。 Zhang J' は、胆囊炎、胃炎による心窩部痛患 者に対して、足三里穴を用いた銊治療を行った ところ、5３0分後に痛みが消失したことを報 告している $(n=3)$ 。また、Li S R 5 8) は、慢性 結腸炎による反復性腹痛患者 61 例に対して大腸 俞、神關にレーザー鍼治療を行ったところ、治 癒73.8\%、改善 $26.2 \%$ 全例で有効であったと報 告している。

3 ）潰瘍性疾患による内臓痛に対する鍼治療に関 する研究 (表 5 )

Debreceni Lら ${ }^{9)}$ は、ランダムに選んだ十二指腸 潰瘍による心窩部痛患者21例に対して中脘穴、 建里穴、足三里穴、内庭穴、胃俞穴、内関穴、 京門穴に鍼治療や耳銊を行ったところ（一日お 
表 5 . 潰瘍による内臓痛

\begin{tabular}{|c|c|c|c|c|}
\hline $\begin{array}{l}\text { 著 者 } \\
\text { (発刊年) }\end{array}$ & $\begin{array}{l}\text { 対 象 } \\
\text { (例数) }\end{array}$ & $\begin{array}{c}\text { 研究デザイン } \\
\text { (比較対照) }\end{array}$ & $\begin{array}{c}\text { 治療穴 } \\
\text { (刺激方法) }\end{array}$ & 結 \\
\hline $\begin{array}{l}\text { Debreceni L et al } \\
\text { (1988) }\end{array}$ & $\begin{array}{c}\text { 十二指晹潰瘍による心窩部痛患者 } \\
\qquad(\mathrm{n}=21)\end{array}$ & 症例集積 & $\begin{array}{c}\text { 中脘, 胃俞, 足三里ほか } 4 \text { 穴 } \\
\text { (鍼刺激) }\end{array}$ & $\begin{array}{l}\text { 76\%で十二指腸潰瘍の治癒とと } \\
\text { もに心窩部痛も消失 }\end{array}$ \\
\hline $\begin{array}{l}\text { Sodipo J O et al } \\
\qquad(1979)\end{array}$ & $\begin{array}{c}\text { 慢性十二指腸潰瘍による内垭痛 } \\
(\mathrm{n}=10)\end{array}$ & 症例集積 & $\begin{array}{c}\text { 中脘, 陽陵泉, 足三里,太衝 } \\
\text { (鍼刺激) }\end{array}$ & $\begin{array}{l}\text { 70\%で内臓痛が完全に消失 } \\
\text { (胃酸の分泌が抑制されたため) }\end{array}$ \\
\hline $\begin{array}{l}\text { Zheng } X L \text { et al } \\
\quad(1985)\end{array}$ & - & 解説 & $\begin{array}{c}\text { 中脘, 天枢,足三里ほか了穴 } \\
\text { (鍼刺激) }\end{array}$ & - \\
\hline
\end{tabular}

きで8１0回の治療）、76\%で十二指腸潰瘍が完 全に治り (内視鏡で確認)、心窩部痛などの症 状もよくなり、残りの $24 \%$ で改善しているこ とを報告している。Sodipo J Oら ${ }^{10)}$ は、慢性十二 指腸潰瘍患者と非潰瘍患者において、中脘穴、 陽陵泉穴、足三里穴、太衝穴用いた銊治療を行 ったところ、両群とも胃酸分泌が銊治療前に比 べて有意に減少し、10例中 7 例で慢性十二指腸 潰瘍に伴う痛みが完全になくなり、残りの 3 例 でも改善したことを報告し、銊治療が単に痛み を押さえるだけでなく、胃酸の分泌抑制などの 原因疾患に対して治療効果を有することを示唆 している。

4) 内臓痛に対する鍼治療に関する研究（表 6) Eriksson M B ら ${ }^{11)}$ は、癌性内臓疼痛患者 5 例 に対して、高頻度の経皮的通電刺激と低頻度の 経皮的通電刺激を行いVASにて鎮痛効果を比較 したが、80\%が無効だったことを報告している。 Sjogren Pら 12) は、デンマークの病院の内科医 に癌患者（78\%が内臓痛を有する）に対する治 療について質問表形式で聞いたところ、1066人 のうちの $5 \%$ が経皮的神経刺激または銊治療を 行ったことがあるとの回答があったと報告して いる。また、Chen $\mathrm{H}^{13)}$ は、種々の疾患に対す るいろいろな治療家の耳鍼治療の有効率を算出 している。急性腹痛に関するものもあるが、残 念ながら引用文献の記載が見られない。

\section{5 ) 解説}

Zheng X Lら ${ }^{14)}$ は、急性腹痛に対する銊治療
法（中脘、天枢、足三里ほか 3 穴の鍼刺激）を 解説している。

以上の臨床論文をまとめてみると、手術適用ま で進行していない消化器系疾患によって生じる内 臓痛は、足三里穴あるいは原因疾患臓器の求心性 神経と同じ皮膚分節上の経穴を中心にした鍼治療 により、概ね $70 \%$ 以上が軽減する可能性が示され ている。その機序としては、内因性鎮痛系の賦活 だけではなく、腸の蠕動運動の抑制、炎症の軽減、 潰瘍の治癒など原因疾患（症状）を改善させるこ とによっても内臓痛を軽減させているものと考え られる。

\section{3. 基礎研究}

基礎研究論文には、動物を対象にしたものとヒ トを対象にしたものとがある。動物を対象にした 銊尒の研究は、メカニズムを追求するためには不 可欠であるが、ヒトと動物の構造上の違い、実験 条件の違いなどから、直接ヒトに適用するにはま だまだ研究を積まなければならない部分も多く、 ヒトを対象にした基礎研究の意義は大きい。内臓 痛に関する動物基礎実験において、内臓痛の誘発 の方法としては、大内臓神経などの内臓痛覚受容 線維の通電刺激、腹腔内へのホルマリン・ metoclopramideなどの発痛物質の注入、バルーン による中腔性藏器の伸展刺激などがある。バルー ンによる結腸一直腸の伸展刺激は、手軽で再現性 も良く、近年、痛みに関する基礎研究において多 く利用されるようになってきている。14編の動物 基礎研究論文は、内臟痛に対する銊鎮痛の脳内中 
表 6. 内臟痛

\begin{tabular}{|c|c|c|c|c|}
\hline $\begin{array}{l}\text { 著 者 } \\
\text { (発刊年) }\end{array}$ & $\begin{array}{l}\text { 対 象 } \\
\text { (例数) }\end{array}$ & $\begin{array}{l}\text { 研究デザイン } \\
\text { (比較対照) }\end{array}$ & $\begin{array}{c}\text { 治療穴 } \\
\text { (刺激方法) }\end{array}$ & 結 \\
\hline $\begin{array}{l}\text { Eriksson M B et al } \\
\text { (1979) }\end{array}$ & $\begin{array}{c}\text { 癌性内臓疼痛患者 } \\
\qquad(\mathrm{n}=5)\end{array}$ & 症例集積 & $\begin{array}{l}\text { 痛みを感じる部位の体表 } \\
\text { (TENS) }\end{array}$ & 無効が $80 \%$ \\
\hline $\begin{array}{l}\text { Sjogren P et al } \\
\quad(1996)\end{array}$ & \multicolumn{3}{|c|}{$\begin{array}{c}\text { 症例集積：医師に癌患者に対する治療について質問 } \\
\text { (78\%で内蔵痛を有する) }\end{array}$} & $\begin{array}{l}\text { 1066例の医師のうち5\%で癌性疼痛 } \\
\text { 患者に鍼治療を行ったことがある }\end{array}$ \\
\hline $\begin{array}{l}\text { Chen H } \\
(1993)\end{array}$ & $\begin{array}{l}\text { 急性腹痛を含む種々 } \\
\text { 療効果を記載（※出兵 }\end{array}$ & $\begin{array}{l}\text { 患に対する色 } \\
\text { 記載はなし) }\end{array}$ & な治療家の耳鍼の治 & - \\
\hline
\end{tabular}

表 7. 動物対象研究

\begin{tabular}{|c|c|c|c|c|c|c|}
\hline 鍼、痛み & 脳内中枢 & 関連化学物質 & 免疫・情動系 & 内臟痛抑制 & 解 説 & 合 計 \\
\hline \hline 動物基礎論文 & 8 & 2 & 2 & 1 & 1 & 14 \\
\hline
\end{tabular}

枢に関するものが 8 編、鍼鎮痛の化学物質に関す るものが 2 編、免疫系・情動系に関するものが 2 編、内臓痛の抑制に関するものが 1 編、総説・解 説が 1 編であった（表 7 ）。

1) 内臓痛に対する鍼鎮痛の脳内中枢に関する研 究 (表 8 )

内臟痛に対する銊鎮痛に関しては脳幹、間脳 などの色々な部位の関与が示されている。

(1)延髄：Huang Zら ${ }^{15)}$ は、麻酔下のウサギを用い て、腹部迷走神経の通電刺激により生じる内臓 体性反射を指標にして、足三里の鍼通電刺激が 内臓体性反射を抑制し、その抑制効果はナロキ ソンにより部分的に拮抗され、延髄孤束核の破 壊により減弱したことから、足三里穴の銊通電 刺激による内臟痛の抑制効果は、オピエート系 が部分的に関与し、その発現には、延髄孤束核 が重要な役割を担っている可能性を示唆してい る。また、Du H J ${ }^{16)}$ も、脳の切断・破壞実 験により、鍼刺激による内臓体性反射の抑制効 果の発現には下位の延髄が関与を示唆している。 (2)間脳（視床・視床下部）：Sumiya ら 17）は、 麻酔下のラットを用いて、バルーンでの結腸一 直腸の伸展により生じる急性内臓痛で誘発され る外腹斜筋の反射性筋電図を指標に、顔面部の 鍼刺激（回旋刺激）による内臓痛の抑制効果 が、痛覚の情動相を中継する核の一つとされて
いる視床内側下核への局所麻酔薬の微量注入に より減弱、消失したことから、この視床内側下 核が内臓痛に対する鍼鎮痛の発現に関与してい る可能性を示唆した。また、Sun Mら ${ }^{18)}$ は、麻 酔下のラットを用い、視床後外側腹側核には、 大内藏神経の通電刺激により活動が増加する二 ューロンと減少するニューロンが存在し、これ らのニューロンの活動は、モルヒネの投与と足 三里の鍼通電刺激によりそれぞれ減少、増加し たことから、視床後外側腹側核が痛み感覚の調 節活動と銊通電刺激による鎮痛効果に関与する

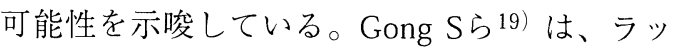
卜を用い、腹腔内への発痛物質の投与により誘 発されるもがき反応が、鍼通電刺激により抑制 され、その抑制効果の発現には、薬物投与実験 により、視床下部室傍核のバソプレッシン作動 性ニューロンが関与することを示している。

(3)その他の部位：Luo D S ら ${ }^{20)}$ は、覚醒下のウサ ギを用い、内臓神経の通電刺激により生じる内 臓体性反射と前肢のwithdraw（引っ込め）反射 の闇值はT10～L 4 の夾脊穴の鍼通電刺激により 上昇し、海馬の背側域の通電刺激を加えるとさ らに閾值が上昇し、海馬の背側域へのナロキソ ンの微量注入により前肢の引つ込め反応の閾値 が拮抗されたことから、海馬の背側域が内臓痛 の鍼鎮痛効果の発現に関与している可能性を示 唆している。Shu Jら ${ }^{21)}$ は、覚醒下のラットを 
表 8. 鍼鎮痛の脳内中枢に関する研究

\begin{tabular}{|c|c|c|c|c|}
\hline $\begin{array}{l}\text { 著 者 } \\
\text { (発刊年) }\end{array}$ & $\begin{array}{c}\text { 実験動物 } \\
\text { (内臟痛の誘発方法) }\end{array}$ & $\begin{array}{l}\text { 刺激部位 } \\
\text { (刺激方法) }\end{array}$ & 鎮痛の指標 & 要 \\
\hline $\begin{array}{l}\text { Sumiya E et al } \\
\qquad(1997)\end{array}$ & $\begin{array}{l}\quad \text { ラット } \\
\text { (バルーンによる直腸の } \\
\text { 伸展刺激) }\end{array}$ & $\begin{array}{l}\text { 顔面部，体幹 } \\
\text { 部，四肢など } \\
\text { (鍼回旋刺激) }\end{array}$ & $\begin{array}{l}\text { 直腸の伸展刺激により } \\
\text { 誘発される外腹斜筋の } \\
\text { 反射性筋電図 }\end{array}$ & 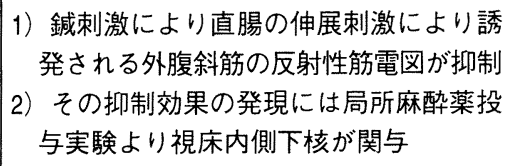 \\
\hline $\begin{array}{l}\text { Shu J et al } \\
\text { (1994) }\end{array}$ & $\begin{array}{c}\text { ラット } \\
\text { (大内臓神経の通電刺激) }\end{array}$ & $\begin{array}{l}\text { 足三里一三陰交 } \\
\text { (銊通電刺激) }\end{array}$ & $\begin{array}{l}\text { 脳内の種々の部位の糖 } \\
\text { 代謝 }\end{array}$ & $\begin{array}{l}\text { 青斑核, 大縫線核, 中脳中心灰白質など } \\
\text { が内臓痛の鎮痛に関与. }\end{array}$ \\
\hline $\begin{array}{l}\text { Gong S et al } \\
\text { (1992) }\end{array}$ & $\begin{array}{c}\text { ラット } \\
\text { (発痛物質の腹腔内投与) }\end{array}$ & $\begin{array}{c}\text { 未記載 } \\
\text { (鍼通電刺激) }\end{array}$ & 内臓痛誘発性writhing反応 & $\begin{array}{l}\text { 鍼通電刺激の内臟痛に対する抑制効果の発 } \\
\text { 現には視床下部室傍核のバンプレッシン作 } \\
\text { 動性ニューロンが関与 (薬物投与実験). }\end{array}$ \\
\hline $\begin{array}{l}\text { Guoxi T } \\
\text { (1991) }\end{array}$ & $\begin{array}{c}\text { ネコ } \\
\text { (大内臟神経の通電刺激) }\end{array}$ & $\begin{array}{c}\text { 足三里 } \\
\text { (鍼通電刺激) }\end{array}$ & $\begin{array}{l}\text { 間脳視床後角群の内臓痛覚 } \\
\text { 刺激反応ニューロのン活動 }\end{array}$ & $\begin{array}{l}\text { 足三里の鍼通電刺激により視床後角群の } \\
\text { 内葴痛興奮ニューロンが抑制. }\end{array}$ \\
\hline $\begin{array}{l}\text { Huang Z et al } \\
\text { (1989) }\end{array}$ & $\begin{array}{c}\text { ウサギ } \\
\text { (腹部迷走神経の電気刺激) }\end{array}$ & $\begin{array}{c}\text { 足三里 } \\
\text { (鍼通電刺激) }\end{array}$ & 内臓体性反射 & $\begin{array}{l}\text { 孤束核が足三里の鍼通電刺激による内臟 } \\
\text { 体性反射の抑制に関与. }\end{array}$ \\
\hline $\begin{array}{l}\text { Sun M et al } \\
\text { (1987) }\end{array}$ & $\begin{array}{c}\text { ラット } \\
\text { (大内臓神経の通電刺激) }\end{array}$ & $\begin{array}{c}\text { 足三里 } \\
\text { (鍼通電刺激) }\end{array}$ & VPLニューロンの活動 & $\begin{array}{l}\text { VPLが內臟痛の調節に関与し，モルルヒネや足 } \\
\text { 三里の通電刺激による抑制効果に関与. }\end{array}$ \\
\hline $\begin{array}{l}\text { Luo D S et al } \\
\qquad(1987)\end{array}$ & $\begin{array}{c}\text { ウサギ } \\
\text { (内臓神経の通電刺激) }\end{array}$ & $\begin{array}{c}\text { 夾脊穴 } \\
\text { (鍼通電刺激) }\end{array}$ & $\begin{array}{l}\text { withdraw反射または内臓 } \\
\text { 体性反射 }\end{array}$ & 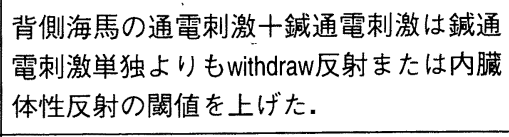 \\
\hline $\begin{array}{l}\text { Du H J et al } \\
\text { (1976) }\end{array}$ & 未記載 & $\begin{array}{c}\text { 未記載 } \\
\text { (鍼通電刺激) }\end{array}$ & 内臓体性反射 & $\begin{array}{l}\text { 銊刺激による内臟一体性反射の抑制には, } \\
\text { 下位延㵦が関与. (脳の切断破壊実験) }\end{array}$ \\
\hline
\end{tabular}

用い、大内臓神経を通電刺激し、生じた内臓痛 により逃避行動を行うまでの刺激閾值を指標に して、放射性同位元素を用いて脳内各部位の局 所糖代謝量を観察したところ、痛み閾值が上昇 した大内臓神経通電刺激十足三里一三陰交間の 鍼通電刺激群では、大内臓神経通電刺激群に比 べて、延䯣・中脳の青斑核・大縫線核・傍巨大 細胞網様核・中脳中心灰白質、視床手綱核にお いて有意に局所糖代謝量が増加し、それらの部 位の内臓痛の鎮痛への関与を示唆した。また、 Guoxi T弓22) は、麻酔下のネコを用いて、視床 後核群において、大内臟神経の通電刺激で興奮 するニューロンが足三里の通電刺激により抑制 し、黒質 (大脳基底核)、後外側腹側核 (視 床)、中脳中心扊白質、尾状核（大脳基底核）、 扁桃核（大脳辺縁系）などの通電刺激でも抑制 し、それらの抑制効果はナロキソンで拮抗され るものとされないものとがあったことから、内
臟痛に対する鍼鎮痛効果の発現には脳内の色々 な部分の、オピエート系、非オピエート系の経 路が複雑に関与している可能性を示唆した。

2 ) 内臓痛に対する鍼鎮痛関連化学物質に関する 研究 (表 9)

Cai Bら 23) は、ウサギを用いて、大内臟神経 の通電刺激により生じる前肢の引つ込め反応の 間值は、T $12 \sim \mathrm{L} 1-2$ の夾脊穴への鍼通電刺 激により上昇し、ドーパミン受容体の阻害剤を 加えるとさらに上昇し、ドーパミン作動薬を加 えると効果は減弱したことから、中枢のドーパ ミン受容体をブロックすることにより、鍼鎮痛 の効果が大きくなることを報告した。また、 Zhang J M ${ }^{24)}$ は、麻酔下のネコを用い、大内 臓神経の通電刺激により生じるA $\delta$ 線維・C 線 維由来の脳波を指標に、内関に鍼通電刺激をす るとモルヒネの投与時と同様にそれぞれの脳波 
表 9. 鍼鎮痛関連化学物質に関する研究

\begin{tabular}{|c|c|c|c|c|}
\hline $\begin{array}{l}\text { 著 者 } \\
\text { (発刊年) }\end{array}$ & $\begin{array}{c}\text { 実験動物 } \\
\text { (内臓痛の誘発方法) }\end{array}$ & $\begin{array}{l}\text { 刺激部位 } \\
\text { (刺激方法) }\end{array}$ & 鎮痛の指標 & 要 \\
\hline $\begin{array}{l}\text { Cai B et al } \\
\text { (1994) }\end{array}$ & $\begin{array}{c}\text { ウサギ } \\
\text { (大内臓神経の通電刺激) }\end{array}$ & $\begin{array}{c}\text { 夾脊穴 } \\
\text { (鍼通電刺激) }\end{array}$ & 内臟痛閾値 & 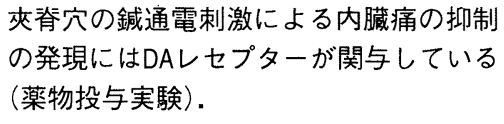 \\
\hline $\begin{array}{l}\text { Zhang J M et al } \\
\qquad(1989)\end{array}$ & $\begin{array}{c}\text { ネコ } \\
\text { (大内臓神経の通電刺激) }\end{array}$ & $\begin{array}{c}\text { 内関 } \\
\text { (鍼通電刺激) }\end{array}$ & 脳波 & $\begin{array}{l}\text { 内関の鍼通電刺激で内臓痛が抑制. ナロキ } \\
\text { ソンの投与で部分的に拮抗されたので, 内 } \\
\text { 因性オピエート様物質の関与が示唆される. }\end{array}$ \\
\hline
\end{tabular}

表10. 免疫系・情動系に関する研究

\begin{tabular}{|c|c|c|c|c|}
\hline $\begin{array}{l}\text { 著 者 } \\
\text { (発刊年) }\end{array}$ & $\begin{array}{c}\text { 実験動物 } \\
\text { (内臟痛の誘発方法) }\end{array}$ & $\begin{array}{l}\text { 刺激部位 } \\
\text { (刺激方法) }\end{array}$ & 鎮痛の指標 & 要 \\
\hline $\begin{array}{l}\text { Yang J et al } \\
\qquad(1994)\end{array}$ & $\begin{array}{c}\text { ラット } \\
\text { (発痛物質の腹腔内投与) }\end{array}$ & $\begin{array}{l}\text { 足三里,大椎,腎俞 } \\
\text { (鍼通電刺激) }\end{array}$ & $\begin{array}{l}\text { 免疫機能や内臓機能の } \\
\text { 血液成分 }\end{array}$ & $\begin{array}{l}\text { 内臓痛状態の対照群に対して鍼通電刺激をす } \\
\text { ると免疫機能や内臓機能の血液成分が改善. }\end{array}$ \\
\hline $\begin{array}{l}\text { Andreev B V et al } \\
\qquad(1981)\end{array}$ & $\begin{array}{c}\text { ラット } \\
\text { (痛覚誘発性情動ストレス) }\end{array}$ & $\begin{array}{c}\text { 大椎 } \\
\text { (鍼通電刺激) }\end{array}$ & 情動反応 & $\begin{array}{l}\text { 鍼通電刺激は痛覚誘発性情動ストレスに } \\
\text { 対して抗不安剂と同じくらい効果があり, } \\
\text { 胃潰瘍の数も有意に減少した. }\end{array}$ \\
\hline
\end{tabular}

の振幅が減少し、C 線維由来の脳波の抑制は、 ナロキソンの投与で部分的に拮抗されたことか ら、内臓痛に対する鍼鎮痛の効果出現には内因 性オピエート物質が関与していることを示した。

3 ) 免疫系・情動系に関する研究（表10）

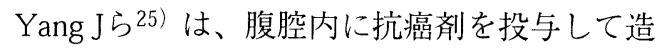
血機能、免疫機能、肝臓 . 腎臓などの機能不 全、内臓痛をなどの副作用を生じさせたラット に対して、足三里または大椎、腎俞の鍼通電刺 激により造血機能・免疫機能や肝臓・腎臓の機 能など改善し、三つの経穴を同時に刺激すると 効果は増大したが、尾部の非経穴部の銊通電刺 激では効果がなかったことを示した。Andreev B Vら26) は、ラットを用い、大椎への鍼通電刺激 により、痛み刺激のストレス暴露により生じた 胃潰瘍の数やストレスに対する攻撃性が、コン トロール群より有意に減少し、その効果は抗う つ剤を投与した場合に匹敵することを示した。

\section{4) 内臓痛の抑制に関する研究（表11）}

Jin S R 5 27) は、覚醒下のネコを用いて、大内 臓神経の通電刺激により誘発される皮膚電位を指
標に、足三里に銊通電刺激を加えると、曲池、人 中、承漿あるいは非経穴部に鍼通電刺激を加えた 時に比べて有意に誘発皮膚電位が抑制し、内臓痛 抑制に対する足三里の特異性を示した。

5 ） Tang D A ${ }^{28)}$ は、1987年時点での鍼炎治効理 論の総説をまとめている。

以上の動物実験に基づく論文をまとめてみると、 内臓痛は、身体のさまざまな部位に行った鍼刺激 により抑制することができ、そのメカニズムとし ては、脳内の痛覚抑制経路が深く関わっているこ とが示されている。

\section{4. 小括}

内臓痛には必ず原因疾患（症状）がある。その 原因は内臓自体にあるために、内臓痛を抑えるこ とだけではなく、原因疾患を治癒させることも非 常に重要となる。動物を対象にした基礎実験研究 からは、内臓痛が生じる現任となっている部位か ら離れた部位での鍼尒刺激によっても、内因性疼 痛抑制系や広汎汎性侵害抑制調節（diffuse noxious inhibitory controls；DNIC）の賦活により、内臓痛 
表11.内臓痛の抑制に関する研究

\begin{tabular}{|c|c|c|c|c|}
\hline $\begin{array}{c}\text { 著 者 } \\
\text { (発刊年) }\end{array}$ & $\begin{array}{c}\text { 実験動物 } \\
\text { (内臓痛の誘発方法) }\end{array}$ & $\begin{array}{c}\text { 刺激部位 } \\
\text { (刺激方法) }\end{array}$ & 鎮痛の指標 & 要 旨 \\
\hline \hline $\begin{array}{c}\text { Jin S R et al } \\
(1987)\end{array}$ & $\begin{array}{c}\text { ネコ } \\
\text { (大内臓神経の通電刺激) }\end{array}$ & $\begin{array}{c}\text { 足三里 } \\
\text { (鍼通電刺激) }\end{array}$ & 内臓皮膚反応 & $\begin{array}{l}\text { 足三里の鍼通電刺激により内臓皮膚 } \\
\text { 反応が抑制（内臓痛の抑制). }\end{array}$ \\
\hline $\begin{array}{c}\text { Tang D A } \\
(1987)\end{array}$ & \multicolumn{3}{|c|}{ 総説・解説 } \\
\hline
\end{tabular}

が抑制されることが示されているが、ヒトを対象 にした臨床研究からは、内臓痛を生じさせる消化 器系の原因疾患（症状）に対して、疾患のある内 臓の支配神経と同じ皮膚分節にある経穴を用いる と治療効果が大きいことが示唆されている。これ らの点から、疾患のある内臓の支配神経と同じ皮 膚分節にある経穴を用いて治療すれば、内臓痛を 抑制するだけではなく、原因疾患（症状）に対す る治療効果も生じるので非常に有効であるものと 考えられる。

内臓痛に対する銊炎治療の効果を扱った研究は、 鍼尒刺激の定量化、経穴等の刺激部位の問題、七 卜に扔ける内臟痛を扱う基礎研究の困難さ、臨床 面における原因疾患との関係などから基礎・臨床 のどちらの分野においても研究が進んでいる状態 ではない。この分野においても、臨床にフィード バックできるような基礎研究、エビデンスの強い 臨床研究を蓄積していく必要がある。

\section{III. 消化機能に対する鍼炎刺激の効果}

\section{1. 消化管に関する鍼炎研究の文献}

消化機能に及ぼす銊尒治療の効果と機序に関す る文献を調査するために、医学中央雑誌（医中 誌：1987-2000年）と、MEDLINE（1966-2000年） のデータを用いて検索した。二つのデータベース では、「銊：acupuncture」を基本のキーワードと したが、医中誌では「銊」を意味するキーワード が、各種存在するので「はり・きゅう：平仮名」 「ハリ：カタカナ」「針」「鍼療法」など、銊扔よ び炎治療に関係する各種のキーワードを用いて検 索した。消化機能に関するキーワードは、「消化 機能:digestive system」を始めとして、「胃」「腸」
などの消化器官の名称を用いて絞り込みを行った。 また言語は、査読の可能な国内文献と英語文献お よび中国語・露垔語文献等では英文抄録のあるも のを対象とした。

その結果、医中誌で95件、MEDLINEで113件の 文献が抽出された。論文の内容を、「器官」と「言 語」で分類して表12に示す。本調査では、鍼治療 の効果のメカニズムに関する論文の調査を目的と したので、臨床報告などで銊治療効果のメカニズ ムに言及していない文献は「その他」の項目に分 類した。

数值から解るように、鍼治療の消化機能に関す る研究は「胃腸」に対する臨床報告が多く、消化 機能に対する銊治療効果の機序について言及して いる論文は数少ないことが解る。

また、1987年にLiらが消化管に関する銊尒研究 を対象に、1979年から1987年までの中国語の文献 調査を主体としたレビュー29）をすでに報告してい る。そこで主要な論文を除き重複をさけ、比較的 数多くの研究論文が発表されている唾液分泌、胃 の運動と胃酸分泌、腸管運動の効果とその機序に ついての文献を紹介する。

\section{2. 唾液分泌に関する銊炎研究（表13）}

1992年にスウェーデンのカロリンスカ研究所の Bromら ${ }^{30)}$ が、口腔の乾燥症状を伴うシーグレン 症候群患者に浅銊をプラセボとした置銊治療を行 つた結果、置銊群に有意な唾液分泌増加の報告を 行い、さらに同グループのDawidsonら ${ }^{31)}$ が、健 康成人に徒手鍼刺激及び銊通電刺激を、頬車、足 三里、合谷、三陰交に行った時の唾液の分泌量を、 「無刺激時」「パラフィン咀嚼刺激時」「クエン酸 刺激時」に測定し、鍼刺激中および銊刺激後に唾 
表12. 論文数

\begin{tabular}{|c|c|c|c|c|c|}
\hline 部 位 & 機能 & 日本語 & 中国語 & 露亜語 & 欧米語 \\
\hline \multirow{2}{*}{ 口 腔 } & 咀嚼運動 & 4 & 0 & 0 & 0 \\
\hline & 唾液分泌 & 1 & 0 & 0 & 6 \\
\hline 食 道 & 蠕動運動 & 0 & 0 & 0 & 1 \\
\hline \multirow{3}{*}{ 胃 } & 胃の運動 & 9 & 21 & 1 & 8 \\
\hline & 胃液分泌 & 9 & 6 & 1 & 3 \\
\hline & その他 & 33 & 10 & 1 & 2 \\
\hline \multirow{3}{*}{ 小 腸 } & 小腸運動 & 5 & 4 & 0 & 3 \\
\hline & 腸液分泌 & 0 & 2 & 0 & 3 \\
\hline & その他 & 25 & 2 & 0 & 2 \\
\hline \multirow{2}{*}{ 大 腸 } & 大腸運動 & 0 & 1 & 0 & 1 \\
\hline & その他 & 7 & 1 & 0 & 1 \\
\hline \multirow{2}{*}{ 膵 臓 } & 膵液分泌 & 1 & 1 & 0 & 3 \\
\hline & その他 & 1 & 0 & 0 & 0 \\
\hline \multirow{2}{*}{ 胆 囊 } & 胆汁分泌 & 0 & 4 & 2 & 1 \\
\hline & その他 & 0 & 1 & 0 & 1 \\
\hline その他 & & 0 & 4 & 1 & 11 \\
\hline
\end{tabular}

MEDLINE : 1966-2000 (total: 113)

+ acupuncture+ digestive system+ saliva + mastication- clinical study

医中誌：1987-2000（total：95）

+胃+腸+唾液+咀嚼+嚥下+食道-会議録

液分泌が増加するが、パラフィン咀嚼やクエン酸 刺激による唾液分泌時では鍼刺激効果が少ないこ とを報告している。

また、鍼治療による唾液分泌増加の機序に関わ る研究として、Dawidsonらは徒手による鍼治療後 の唾液中の神経ペプタイドのCGRP ${ }^{32 ） と V I P}{ }^{33)} の$ 濃度を測定し、鍼治療による唾液分泌の増加と血 管拡張物質であるCGRPやVIPの増加が鍼治療後の 唾液中に認められる事を報告している。

同様に、小俣ら ${ }^{34)}$ はシーグレン患者の、顔面 部の経穴に $20 \mathrm{~Hz}$ で鍼通電刺激を行うと頸部に行っ た場合より唾液分泌が増加すること、および鍼治 療を10回繰り返すことによりシーグレン患者の乾 燥症状か軽減することを問診表 (Dray mouse score) で評価した臨床報告を発表している。

これらの報告から、健康人や口腔乾燥症患者で 鍼刺激により唾液分泌が増加することが証明され るが、その機序として小俣らによる唾液腺のある 顔面部への局所刺激が他の部位の刺激より有効な
こと、またDawidsonの報告にあるように唾液腺の 血管拡張を示唆する局所血管拡張物質の検出され ることから、刺激局所における軸索反射による分 泌増加が有力であると考えられている。しかし、 副交感神経や交感神経による直接的な唾液分泌や 交感神経を介した血管拡張による分泌増加などの 存在が考えられ、詳細についてはさらなる検討が 必要であると考えられる。

\section{3. 胃の運動に関する鍼炎研究（表14）}

鍼治療効果の機序に関連の深い、体性-内臓反 射に関する基礎研究は、1975年にSatoらにより麻 酔ラットで腹部に与えたピンチ刺激が胃の内圧を 低下させることが報告35) され、この反応が脳や迷 走神経が起始する延䯣を除去しても起こり、交感 神経が胃に分布する経路の内臓神経を切断すると 消失することから、腹部のピンチ刺激による胃内 圧抑制反応は春髄で起こる反射性反応であること を証明した。さらにこの反応を、Kametaniら ${ }^{36)}$ が 
表13. 唾液分泌

\begin{tabular}{|c|c|c|c|c|c|c|c|}
\hline 著者 & 発行年 & 対象 & 例数 & 刺激方法 & 測定 & 結果 & 雑誌 \\
\hline Dawidson,I. & (1997) & 健康人 & (8) & $\begin{array}{c}\text { 徒手銊および鍼通電 } \\
\text { (st3-6-36,Li-4,sp-6) }\end{array}$ & \begin{tabular}{|l} 
唾液量（無刺激） \\
唾液量(パラフィン勗嚼時) \\
唾液量(クエン酸刺激時)
\end{tabular} & 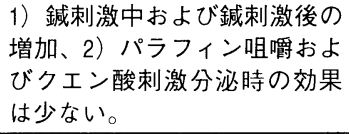 & $\begin{array}{l}\text { Journal of Oral } \\
\text { Rehabilitation }\end{array}$ \\
\hline Brom,M. & (1992) & 乾燥症患者 & (21) & $\begin{array}{l}\text { プラセボは浅い銊、 } \\
\text { 20分間置鍼を週2回- } \\
\text { 6週間 }\end{array}$ & 唾液量 & $\begin{array}{l}\text { 鍼刺激によりプラセボ群より唾 } \\
\text { 液量が増加。 }\end{array}$ & $\begin{array}{l}\text { Oral Surg Oral } \\
\text { Med Oral Patho }\end{array}$ \\
\hline Dawidson,I. & (1998) & 乾燥症患者 & (65) & $\begin{array}{l}\text { st3-6-36,Li-4,sp-6に徒 } \\
\text { 手で得気を得るまで } \\
\text { 刺激 }\end{array}$ & 唾液量と唾液中のVIP & 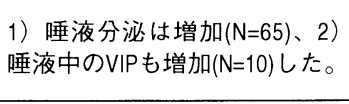 & Neuropeptides \\
\hline Dawidson,I. & (1999) & 乾燥症患者 & (65) & $\begin{array}{l}\text { st3-6-36,Li-4,sp-7に徒 } \\
\text { 手で得気を得るまで } \\
\text { 刺激 }\end{array}$ & $\begin{array}{l}\text { 唾液量と喠液中の } \\
\text { CGRP }\end{array}$ & $\begin{array}{l}\text { 1) 唾液分泌は増加( } \mathrm{N}=65) \text { 、2) 唾 } \\
\text { 液中のCGRPも増加( } \mathrm{N}=14) し た 。\end{array}$ & Neuropeptides \\
\hline 小俣浩、他 & (2000) & $\begin{array}{l}\text { シェーグレン } \\
\text { 患者および } \\
\text { 健康人 }\end{array}$ & $\begin{array}{c}\text { Nomal }=10 \\
s j s=15\end{array}$ & $\begin{array}{c}\text { 頚部銊通電1および } \\
20 \mathrm{~Hz} \text { 顔面部銊通電1 } \\
\text { および2OHz }\end{array}$ & 唾液量 & $\begin{array}{l}\text { 1) sjsで頚部より顔面の } 20 \mathrm{~Hz} の \\
\text { 鍼通電が有効、2) dray scoreの } \\
\text { 調査で10週間後口腔乾燥症状 } \\
\text { が改善 }\end{array}$ & $\begin{array}{l}\text { 日本温泉気候 } \\
\text { 物理医学会誌 }\end{array}$ \\
\hline
\end{tabular}

詳細に検討し、麻酔ラットの様々な部位にピンチ 刺激を加えると、腹部や背部では胃運動の抑制反 応が出現するのに対して、四肢では胃運動の充進 が認められること、腹部刺激時の抑制反応では胃 交感神経活動が増加し、四肢刺激時の充進反応で は胃迷走神経活動が増加する。また、この反応が 脊髄動物では抑制反応のみになることから腹部刺 激による抑制反応は脊髄反射による交感神経の興 奮で起こり、また四肢への刺激による元進反応は 上脊髄性反射による迷走神経の興奮で起きている ことを解明した。

銊尒研究の分野では、1978年の第 5 回国際鍼尒 学会で、森らがウサギの足三里に雀啄刺激を加え た際の胃の運動をバルーン法で観察したところ、 胃内圧上昇反応と足三里穴部を支配する坐骨神経 の切断側では胃内圧上昇反応が消失することを報 告37）している。また、1991年にKudo Tらにより 麻酔イヌの背部にある胆俞穴の鍼通電刺激により、 胃運動のリズムが遅延と胃平滑筋の電気活動が抑 制されることを胃の平滑筋筋電図で観察し体性感 覚刺激 (ピンチ刺激) 時と同様の反応が鍼刺激で

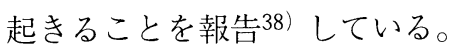

1993年にSatoらは、前報35.36) と同様の手法で鍼 刺激による効果を観察し、全身の各部位に銊の回 旋術を行った時にピンチ刺激と同様の胃運動の抑 制と充進が起こり、腹部では交感神経を介した抑
制が四肢では迷走神経を介した六進が反射性に起 きることを証明している。39）さらに、山口らは刺 激強度の定量が可能な銊通電刺激により腹部で抑 制反応が後肢で充進反応が起こることを確認し、 腹部刺激では肋間神経から後肢刺激では脛骨神経 からそれぞれの求心性複合活動電位を記録し、腹 部刺激では C 線維が興奮する強度で、後肢刺激で は A 線維に加え C 線維が興奮する強度で反応が起 こることを観察し、体幹部と後肢では鍼刺激を伝 える神経線維の種類が異なることを報告40)してい る。

このように、鍼刺激の胃運動に対する効果とそ のメカニズムに関して、国内で数多の研究者が実 験を行い鍼刺激の胃運動の反応の機序が明確にな りつつある。

\section{4. 胃酸分泌に関する銊炎研究（表15）}

欧米で初めて紹介された胃酸分泌に関する銊治 療の論文は、1979年に報告されたラゴス大学（ナ イジェリア）のSodiphoら10)によるもので、十二 指腸潰瘍患者と非潰瘍消化不良の患者の 2 群に対 して、鍼や鍼通電治療等を 6 週間行ったところ、 胃痛の消失とともに十二指腸患者群の最大刺激酸 分泌量が減少していたことから、鍼治療の効果は 胃酸分泌の抑制に起因すると考察している。

銊の基礎研究の分野では、1984年にロチェス夕 
表14. 胃運動

\begin{tabular}{|c|c|c|c|c|c|c|c|}
\hline 著者 & 発行年 & 対象 & 例数 & 刺激方法 & 測定 & 結 果 & 雑誌 \\
\hline Sato, A & (1975) & 麻酔ラット & 14 & $\begin{array}{c}\text { 体性感覚刺激 } \\
\text { (ピンチ、20秒間) }\end{array}$ & バルーン & 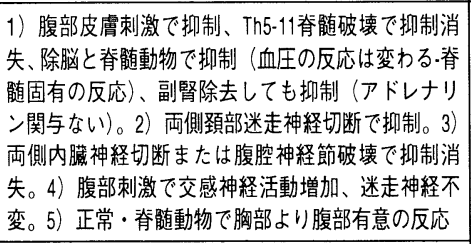 & Brain Res. \\
\hline Kametani, $\mathrm{H}$ & (1979) & 麻酔ラット & 20 & $\begin{array}{c}\text { 体性感覚刺激 } \\
\text { (ピンチ、20秒間) }\end{array}$ & バルーン & $\begin{array}{l}\text { 1) 腹部刺激は胃運動を抑制、内葴神経活 } \\
\text { 動は増加、切断で胃運動抑制消失。2)足 } \\
\text { 蹠刺激はえ進、迷走神経活動増加、切断 } \\
\text { で消失、少し抑制。3）腹部・足蹠同時刺 } \\
\text { 激は腹部の抑制反応が有意。 }\end{array}$ & $\begin{array}{l}\text { Juornal of } \\
\text { Physiology }\end{array}$ \\
\hline 森秀太郎 & (1978) & 麻酔ウサギ & 5 & $\begin{array}{l}\text { 足三里鍼通電（2-20 } \\
\mathrm{Hz} 、 30 \text { 秒間または徒 } \\
\text { 手鍼(雀啄、30秒間） }\end{array}$ & $\begin{array}{l}\text { バルーン\& } \\
\text { 胃壁筋電図 }\end{array}$ & $\begin{array}{l}\text { 1) 胃運動亢進 }(38 / 50) 、 \text { 坐骨神経切断でえ } \\
\text { 進消失。2) 深麻酔で筋電図え進反応消 } \\
\text { 失、浅麻酔で筋電図六進後迷切で消失。 }\end{array}$ & 日鍼炎誌 \\
\hline Kudo, T & (1991) & 意識下イヌ & 5 & $\begin{array}{l}\text { 足三里、胆俞、手三 } \\
\text { 里の銊通電 }(2 \mathrm{~Hz} \text { 、 } \\
\text { 20分間 })\end{array}$ & 胃壁筋電図 & $\begin{array}{l}\text { 1）BERの頻度が胆俞>手三里>コントロ } \\
\text { 一ルで前值より低下、APは胆俞が有意に } \\
\text { 低下。2）胆俞は胃の運動を抑制する。 }\end{array}$ & Am.J.Chi.Med. \\
\hline Sato, A & (1993) & 麻酔ラット & 46 & 徒手（旋撚）-60s & バルーン & $\begin{array}{l}\text { 1) 足-胃運動え進（迷走神経活動増加）。 } \\
\text { 2) 腹-胃運動抑制（交感神経活動増加）。 } \\
\text { 3）ナロキソン影響なし。 }\end{array}$ & Neurosci.Res. \\
\hline 山口真二郎 & (1996) & 麻酔ラット & 16 & EA-30s-腹/足蹠 & バルーン & $\begin{array}{l}\text { 1) 腹部刺激で胃運動抑制、2) 内神経切断で } \\
\text { 抑制反応消失、、3) 足蹠刺激で胃運動亢進、 } \\
\text { 4) 迷走切断で亢進反忍消失、5) 足蹠刺激は } \\
\text { 大腿および脛骨神経のC 線維が関与、6) 腹 } \\
\text { 部刺激は肋間神経のA A おびC 線維が関与 }\end{array}$ & 自律神経 \\
\hline
\end{tabular}

一大（米国）のZhouらが、無麻酔の胃瘦犬を用い て足三里・内関・脾俞に 2 時間の鍼通電刺激を加 えた際の胃酸分泌の抑制を観察し、この反応が迷 走神経遮断薬（アトロピン）の投与や銊刺激部位 の局所麻酔（プロカイン）で消失することから体 性-自律神経反射による胃酸分泌抑制反応と報告 41）している。また、同大のJinらは意識下のイヌ でアミノ酸食摂取時の胃酸分泌克進が銊刺激によ り抑制されることを観察し、この胃酸抑制反応が ナロキソン投与で消失することから、鍼鎮痛と同 じく内因性オピオイドが関与した機序であると報 告42)している。

一方、上海の恒らは、麻酔ラットの胃の中を生 理食塩水で環流しその p H值の変化から胃酸分泌 を観察し、足三里の銊通電刺激で迷走神経切断や ナロキソン投与の影響を受けない胃酸分泌充進を 報告43)している。また、野口らは、麻酔ラットで 同様の胃環流法を用いて胃酸分泌を観察し、足三 里の銊通電刺激による胃酸分泌は㐫進反応を観察 し、この反応が坐骨神経と迷走神経の切断で消失
し内臟神経切断では残存することから、体性-自律 神経反射による胃酸分泌充進反応を報告 ${ }^{44,45)}$ して いる。

鍼刺激による胃酸分泌反応の報告には相反する 結果の報告が多数有り一定の結果およびメカニズ ムは不明である。Pomeranzは著書 (Textbook of acupuncture）の総説 ${ }^{46)}$ の中でNoguchi (1996) ${ }^{45)}$ とJin (1996) ${ }^{42 ）}$ の報告を取り上げ、ふたつの研究 の大きな違いは、麻酔の有無であり意識下の動物 の反応の場合は銊刺激による動物のストレスの問 題を解決しなければ成らないと指摘している。し かし、麻酔の有無以外にも胃酸分泌では、情動や ホルモンなど関与する因子が多いため、銊の効果 の解明には、まだまだ解決すべき問題が数多く残 されていると考えられる。

さらに胃酸分泌と関連の深い胃潰瘍に関する研 究では、本郷らが実験動物（ラット）で、酢酸を 用いた胃の焼妁潰瘍モデルに対して、足三里と胃

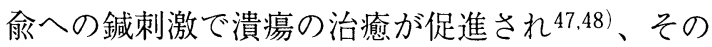
機序として潰瘍底肉芽組織の血流増加が大きくか 
表15. 胃酸分泌

\begin{tabular}{|c|c|c|c|c|c|c|c|}
\hline 著者 & 発行年 & 対象 & 例数 & 刺激方法 & 測定 & 結 果 & 雑誌 \\
\hline Sodip.J & (1979) & 潰瘍ヒト & 10 & $\begin{array}{l}\text { 置鍼、鍼通電 }(2-3 \mathrm{~Hz}, \\
30 \text { 分間)および生姜 } \\
\text { 炎を3回/週/6週間、 } \\
\text { (中脘、陽稜泉、足 } \\
\text { 三里、太衝) } \\
\end{array}$ & \begin{tabular}{|l|} 
胃酸直接採取 \\
後、基礎酸分泌 \\
量(BAO) 最大 \\
刺激酸分泌量 \\
(MAO)測定 \\
\end{tabular} & $\begin{array}{l}\text { 1) } \mathrm{BAO} \text { 減少、MAO減少。2) 潰瘍患者の } \\
\text { 鍼による痛みの除去に胃酸の減少が関 } \\
\text { 与。 }\end{array}$ & Am.J.Chin.Med. \\
\hline Zhou, L & (1984) & 意識下イヌ & 5 & $\begin{array}{l}\text { 鍼通電(2h)および,徒 } \\
\text { 手銊刺激 }\end{array}$ & $\begin{array}{l}\text { 胃瘻より胃酸採 } \\
\text { 取 }(\mathrm{pH} \text { 、塩酸量、 } \\
\text { 重炭酸量測定) } \\
\end{array}$ & $\begin{array}{l}\text { 1) 偽鍼<徒手鍼<鍼通電埜順に胃酸 } \\
\text { 減少、重炭酸え進。2）刺針部局麻で反 } \\
\text { 応消失。3)アトロピン投与で反応消失 } \\
\end{array}$ & Life Science \\
\hline 恒健生 & (1986) & 麻酔ラット & 10 & 鍼通電(足三里) & $\begin{array}{l}\text { 胃内環流(灌流 } \\
\text { 液のpHの測定) }\end{array}$ & $\begin{array}{l}\text { 1) 胃酸分泌穴進、2）迷走神経切断で } \\
\text { 消失、3）通電+ナロキソン影響なし。 } \\
\text { 4）モルヒネ投与でえ進 } \\
\end{array}$ & 上海中医薬誌 \\
\hline 野口栄太郎 & (1991) & 麻酔ラット & 56 & $\begin{array}{l}\text { 銊通電（足三里, } 20 \\
\text { 分間） }\end{array}$ & $\begin{array}{l}\text { 胃内環流(灌流 } \\
\text { 液のpHの測定) }\end{array}$ & $\begin{array}{l}\text { 1) 足三里鍼通電で胃酸分泌方進、2） } \\
\text { 座骨神経切断で反応消失。 3）クラー } \\
\text { レ投与後もえ進反㤁出現 }\end{array}$ & 埼玉医学会誌 \\
\hline Jin, $H$ & (1996) & 意識下イヌ & 5 & $\begin{array}{l}\text { 1)無刺激, 2)偽鍼, 3)銊通 } \\
\text { 電 (脾入俞、足三里、内関、 } \\
\text { 75分間),4)鋮通電+ナロキ } \\
\text { ソン投与, 5)ナロキソン } \\
\text { 投与, 6)ソマトスタチン } \\
\text { 投与、VIP投与,ベータ・ } \\
\text { エンドルフィン投与 } \\
\end{array}$ & 胃瘻 & 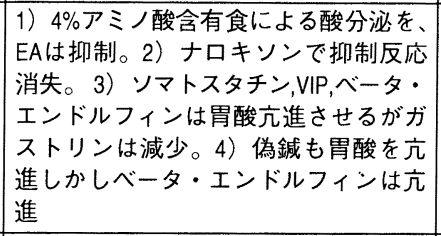 & $\begin{array}{c}\text { American Juornal } \\
\text { of Physiology }\end{array}$ \\
\hline Noguchi, E & (1996) & 麻酔ラット & 56 & $\begin{array}{l}\text { 銊通電（足三里また } \\
\text { は手三里） }\end{array}$ & $\begin{array}{l}\text { 胃内環流(灌流 } \\
\text { 液のpHの測定) }\end{array}$ & $\begin{array}{l}\text { 1) 足三里>手三里の鍼通電で胃酸え } \\
\text { 進、2）坐骨神経、迷走神経切断で消失、 } \\
\text { 3）内臓神経切断でえ進反応 }\end{array}$ & $\begin{array}{c}\text { Japan Journal of } \\
\text { Physiology }\end{array}$ \\
\hline
\end{tabular}

かわっていることを示し49)、さらに水浴ラットで のストレス潰瘍のモデルでは銊刺激で潰瘍形成の 予防効果に関する報告がある50)。

\section{5.小腸運動に関する鍼炎研究（表16）}

小腸運動に関する体性感覚刺激の研究では、 1976年にSatoらが、十二指腸に挿入したバルーン の内圧変化から十二指腸運動を観察し、腹部に加 えたピンチ刺激により十二指腸運動が抑制され、 この反応は迷走神経を切断や脊髄動物では観察さ れるが内臓神経の切断により消失することから、 脊髄における交感神経性反射性反応であると報告 51）している。さらに、1980年のKoizumiの報告で は、観察部位を小腸に変えて同様の実験を行い、 小腸運動は腹部のピンチ刺激で抑制され足蹠や胸 頚部では充進する反応は、腹部刺激の抑制時には 交感神経が興奮し、足蹠刺激の充進時には交感神 経が抑制されることが報告52)されている。

銊尒の実験的研究は、1929年に藤井秀二により 行われ大阪医学会誌に報告されている。藤井は、 無麻酔固定ウサギの腹部に開けた小孔から小腸運 動を肉眼で計測し、接触鍼刺激を胸部に行った時
に小腸の運動は一過性の増加後に減少すること報 告53)している。1994年にIwaらは、経口的に胃に 投与した墨汁が腸管の中を移動した距離を無麻酔 マウスで観察し、平常時では腹部鍼刺激により立 進し尒刺激により抑制されること、腸の運動を立 進するワゴスチグミン投与後では腹部の鍼尒刺激 は逆に抑制反応にかわり、アトロピン投与による 抑制時には元進反応となり、またエピネフリンで 交感神経を刺激し運動を抑制した場合は反応は観 察されないことから、鍼尒刺激は小腸自身の緊張 状態により亢進にも抑制にも働く、交感神経を介 した 2 相性反応であることを報告54) している。野 口らは、麻酔ラットを用い、バルーンを用いて鍼 通電刺激による十二指腸運動の変化を観察し、後 肢足蹠刺激で迷走神経を介するえ進および腹部刺 激で脊髄分節性の抑制反応が起きることを報告55) している。小腸運動に対する効果の機序は、腹部 刺激による抑制反応は、脊髄性反射を介した交感 神経の興奮による抑制であるが、足蹠刺激による 克進反応の場合は、上脊䯣性の交感神経を介した 小腸六進反応 (Koizumi $)^{52)}$ と迷走神経を介した 十二指腸の㠵進反応（野口） ${ }^{55)}$ の報告があり、腸 
表16. 腸運動

\begin{tabular}{|c|c|c|c|c|c|c|c|}
\hline 著者 & 発行年 & 対象 & 例数 & 刺激方法 & 測定 & 結 果 & 雑誌 \\
\hline 藤井秀二 & $(1929)$ & $\begin{array}{l}\text { 意識下 } \\
\text { ウサギ }\end{array}$ & 5 & 接触鍼刺激 & $\begin{array}{l}\text { 腹部開創部 } \\
\text { より目視 }\end{array}$ & 1）小腸運動は一過性の亢進の後抑制 & 大阪医学会誌 \\
\hline Sato, $Y$ & $(1976)$ & 麻酔ラット & 28 & 体性感覚刺激 & バルーン & $\begin{array}{l}\text { 1) 腹部ピンチ刺激で十二指腸運動抑制。 } \\
\text { 2) 迷走神経切断で抑制反応。3）脊䯣切断 } \\
\text { で抑制反応。4）内臟神経切断で抑制消失。 }\end{array}$ & Neurosci.Res. \\
\hline Koizumi, $\mathrm{K}$ & $(1980)$ & 麻酔ラット & 36 & 体性感覚刺激 & バルーン & 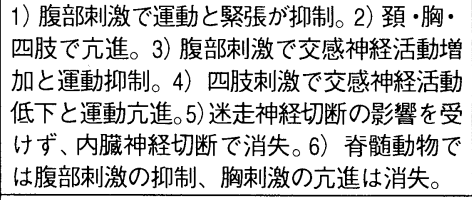 & Brain Res. \\
\hline Iwa, $\mathrm{H}$ & (1994) & 意識下マウス & & 円皮鍼・炎 & 炭液移動 & $\begin{array}{l}\text { 1) ワゴスチミンによるえ進を鍼炎は抑制。 } \\
\text { 2) アトロピンによる抑制を銊炎は促進。 } \\
\text { 3) エピネフリンによる抑制を鍼炎では不変 }\end{array}$ & Am.J.Chin.Med \\
\hline
\end{tabular}

管運動の測定部位による違いが考えられている。 また、岩らの研究でも腸運動の克進時は抑制反応 が出現している。彼らの臨床研究4)によれば、イ レウス患者の腸管運動立進が鍼治療により抑制さ れたと報告されていることから、バルーン法によ る腸管運動の測定はイレウス状態と考えられ、充 進状態の腸管運動については同じ機序であると考 えられる。しかし、腸管の状態により反応が異な る可能性も示唆される。

\section{6. 小括}

唾液分泌では、臨床研究が先行し機序の研究と しては血管拡張物質の関与が報告されているのみ で、そのほかの機序については研究が進んでいな い。

胃の運動では、日本の研究者により、銊の効果 の神経性機序は明らかになりつつあり、脊髄反射 を介した交感神経の興奮による抑制反応と脊髄よ り上位の中枢を介した迷走神経の興奮による京進 反応が考えられている。鍼尒臨床で「胃の六炎」 として尒が多用されてきた理由は、体幹部の刺激 による胃運動の抑制には C 線維を興奮させるよう な比較的強い刺激が必要であったためと考えられ、 足三里などの四肢への刺激では A 線維を興奮させ るような比較的弱い刺激から胃運動の充進を起こ す可能性がある。したがって、胃の運動を高めよ うとするとき、手足の経穴への刺激は軽度でも可 能であると考えられる。しかし、脳を介する反射
なので、意識のある状態のヒトでは情動などの干 渉を受け反応が一定しない可能性も考慮しなけれ ばならない。

胃酸分泌では、体性-自律神経反射や内因性才 ピオイドを介した反応報告があり、胃酸分泌に対 する一定の結果はまだでていない。胃潰瘍の予防 効果の検討も含め、銊による胃酸分泌への効果の 機序については、さらに詳細な検討を進める必要 がある。

腸管運動では、十二指腸・小腸に関しては、脊 䯣反射を介した交感神経の興奮による抑制反応と 春髄より上位の中枢を介した交感神経の抑制抢よ び迷走神経の興奮による亢進反応が示唆されてお り、腸管の部位により介する自律神経の違いが示 唆されている。また、大腸においては臨床・基礎 ともに報告が認められず研究が進んでいない。

消化管には上記に列挙した以外にも、まだ多く の器官・機能、未解決の鍼尒刺激に対する反応が あり、基礎研究分野では一つ一つの器官に対して 鍼炎刺激による反応の機序の検討をさらに進めて ゆく必要があると考えられる。

\section{N. 消化器症状に対する鍼炎治療の効果}

\section{1. 消化器疾患に対する銊炎の応用の現状}

どのような消化器疾患に対して鍼炎治療が応用 されているのかを知るため、該当する文献を可能 な限り検索した。検索にはMEDLINE、医学中央 
表17. 実験デザインと報告件数

\begin{tabular}{|c|c|c|c|c|}
\hline & 症例報告 & 症例集積 & $\begin{array}{c}\text { 症例対象研究 } \\
\text { (コホート研究含む) }\end{array}$ & $\begin{array}{c}\text { ランダム化比較試験 } \\
\text { (RCT) }\end{array}$ \\
\hline アカラシァ & & 2 & 2 & \\
\hline 逆流性食堂炎 & & & 2 & 1 \\
\hline 胃十二指腸潰瘍 & 1 & 1 & 1 & \\
\hline $\begin{array}{c}\text { 機能性胃腸症 } \\
\text { (non-ulcer dyspepsia:NUD) } \\
\text { (functional dyspepsia:FD) }\end{array}$ & & 1 & 1 & \\
\hline 虫垂炎 & & 1 & & \\
\hline イレウス & 1 & 2 & & \\
\hline 過敏性腸症候群 & & 1 & & \\
\hline 膵炎 & & & & 1 \\
\hline
\end{tabular}

誌雑誌などを用いた。

これまでに鍼治療や、経穴への通電治療が施行 された消化器疾患は、

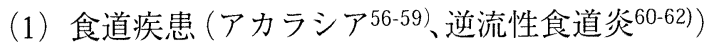

（2）胃疾患 (胃潰瘍 ${ }^{10,63,64)}$ 、慢性胃炎65)、胃ア卜 二-66-67)、機能性胃腸症 (functional dyspepsia: FD) ${ }^{68-69)}$ )

（3）小腸 - 結腸疾患（過敏性腸症候群70）、虫垂炎 71)、イレウス ${ }^{4,72,73)}$ )

（4）肝 · 胆 - 膵疾患 (胆石症 ${ }^{74,75)}$ 、慢性肝炎 ${ }^{76-79) 、 ~}$ 膵炎80)

などが見られたが、これらはいずれも鍼治療や TENSなどの通電治療に関する報告であり、炎治 療を用いた報告は慢性肝炎に関する一編76)のみ しか見受けられなかった。そして臨床効果につい てrandomized controlled trial（RCT）により検討さ れたものは、膵炎80）と逆流性食道炎62）に関する 報告のみで、経穴への通電治療（鍼およびTENS） がこれらの症状改善に有効であることを述べてい た。だが、他の報告は症例報告や症例集積の段階 で、且つ全般的に論文数も極めて少ないため、各 消化器疾患に対する銊の効果を実証するには至る ことができない状況であることを認識せざるを得 ない（表17）。現状では症例研究からの知見を参 考にすることは重要だが、今後、これらの疾患に 対する銊炎の効果を実証するためには、より精度
の高い臨床試験を適用し、さらにその追試を通し て吟味することが必要であろう。なおごく最近に、

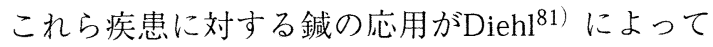
reviewされており、本稿と合わせて参考にしてい ただきたい。

\section{2. 消化器症状（吐き気・嘔吐）に対する銊治療} の効果（表18、表19）

一般的に消化器症状としては、吐き気（悪 心）・嘔吐、上腹部痛、胸やけ、腹部膨満、腹 痛、げっぷ、下痢、便秘などがあげられる。これ らの内、銊尒治療の臨床効果については吐き気・ 嘔吐に対する検討が数多くなされており、その成 果の一部はNIHの声明文82)でも取り上げられ、鍼 の効果として認められるに至った。どのような吐 き気・嘔吐に対して鍼治療が応用されているのか を展望すると、（1）手術後の吐き気・嘔吐83-93) (腹部開腹手術後、腹腔鏡手術後、帝王切開術後な

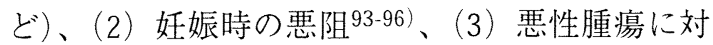
する化学療法時の吐き気97-101)、などで用いられて おり、現時点では約100編近くの報告を検索する

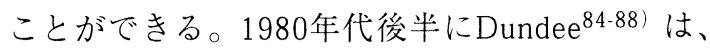
婦人科小手術を受けた患者の術後の吐き気・嘔吐 に対して鍼治療を試みたところ、プラセボ群に比 して銊治療群で改善を得、さらにその効果は制吐 剂による効果に匹敵していた88) ということや、化 
表18. Dundeeらによる報告の概要

\begin{tabular}{|c|c|c|c|c|}
\hline $\begin{array}{l}\text { 発表年度 } \\
\text { 雑誌名 }\end{array}$ & 対象数 & 実験デザイン & 鍼の手法 & 結果 \\
\hline $\begin{array}{c}1986 \\
\text { British Med. J }\end{array}$ & $\begin{array}{c}\text { 婦人科小手術 } \\
N=75\end{array}$ & $\begin{array}{c}\text { プラセボ } \\
\text { コントロール }\end{array}$ & $\begin{array}{l}\text { 内関への } \\
5 \text { 分間の置鍼 }\end{array}$ & $\begin{array}{l}\text { プラセボ群に比して鍼治療群で } \\
\text { 改善 }\end{array}$ \\
\hline $\begin{array}{c}1987 \\
\text { Anaesthesia }\end{array}$ & $\begin{array}{c}\text { 婦人科小手術 } \\
N=31\end{array}$ & $\begin{array}{c}\text { 投薬群 } \\
\text { VS } \\
\text { 置銊群 } \\
\text { VS } \\
\text { 鍼通電群 } \\
\end{array}$ & $\begin{array}{l}\text { 内関への5分間の } \\
\text { 置鍼あるいは鍼通電 }\end{array}$ & $\begin{array}{l}\text { 置銊群と鍼通電群での症状の程 } \\
\text { 度は、制吐剤の投与と変わらな } \\
\text { い程有効であった }\end{array}$ \\
\hline $\begin{array}{c}1987 \\
\text { Lancet }\end{array}$ & $\begin{array}{c}\text { 癌患者の化学療法 } \\
\quad \mathrm{N}=10\end{array}$ & $\begin{array}{c}\mathrm{RCT} \\
\text { プラセボコントロール }\end{array}$ & 内関への鍼通電 & $\begin{array}{l}\text { 鍼通電時には症状が出現しない } \\
\text { ことが多かった }\end{array}$ \\
\hline $\begin{array}{c}1989 \\
\text { J. Royal Soci. Med. }\end{array}$ & $\begin{array}{c}\text { 癌患者の化学療法 } \\
\mathrm{N}=105\end{array}$ & $\begin{array}{c}\mathrm{RCT} \\
\text { クロスオーバなど }\end{array}$ & 内関への鍼通電 & 対照群に比して鍼治療群で改善 \\
\hline
\end{tabular}

表19. 乗り物酔い（motion sickness）に対する検討

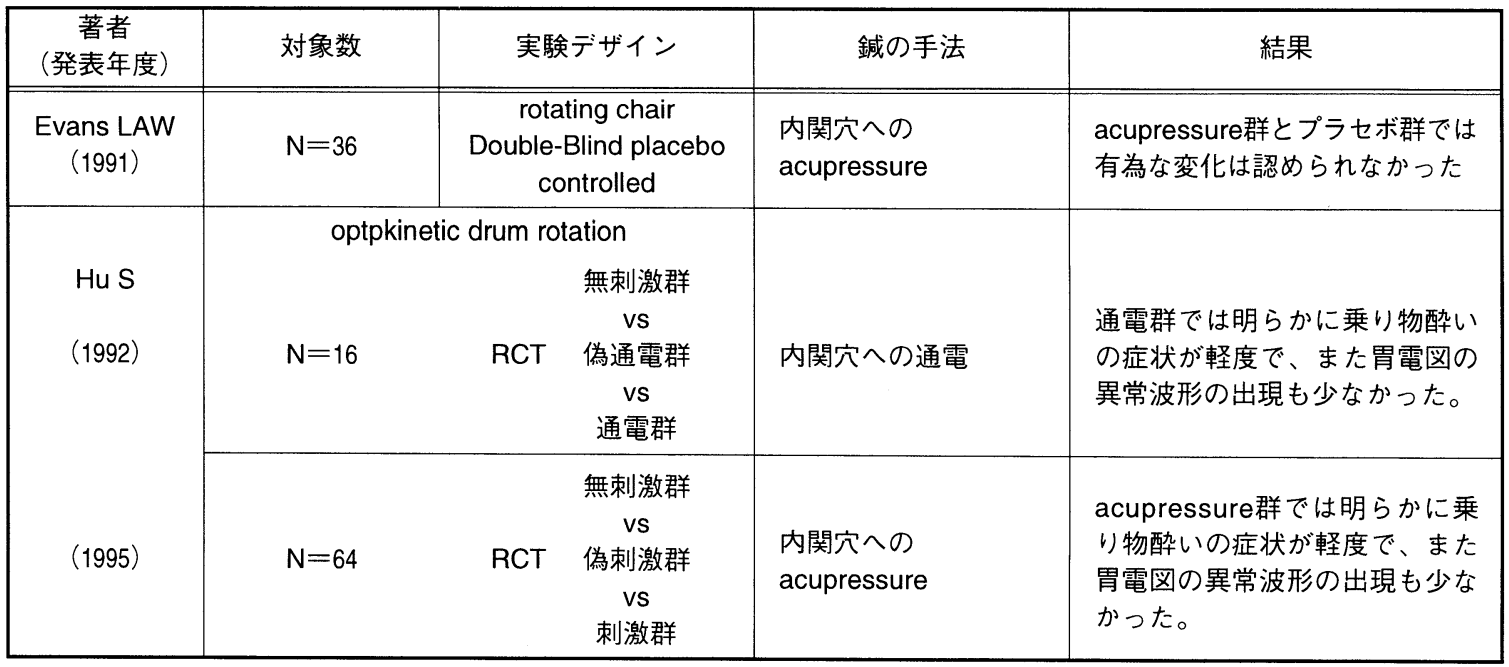

学療法を施行されている癌患者において鍼通電 （10HZ、心地よい程度の強度）を行うと対照群よ りも症状の出現が抑えられることをRCTにより示 した97-100)（表18）。Dundeeによる試みが引き金と なり、以降、吐き気・嘔吐に対する鍼治療の臨床 応用が多く検討され、近年ではRCTによる検討も さらに積み重ねられ、1995年と1996年には各 2 編 ずつ、97年には 6 編、98年には 3 編が発表されて いる状況にある。そしてsystematic reviewが、96年

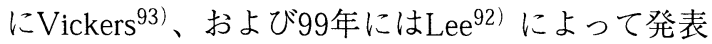
され、これらの研究の積み重ねを経て、成人で手 術後早期に訴えられる吐き気・嘔吐、妊娠時の悪 阻、化学療法時の吐き気・嘔吐に対しては、内関
穴への鍼治療が有効であるという結論が支持され るに至った。しかし一方では、小巟の吐き気・嘔 吐については、効果が得られないという結果が複 数の報告で一致してもいる。成人と小児では鍼治 療の効果が異なるという点に興味を持つところで あろう。また、第 49 回の本学会学術大会（兵庫） において井上ら102）は吐き気・嘔吐の必要治療回 数（NNT）をCCT (臨床比較試験) 文献から求 め、同様の傾向にあることを報告していた。

そしてこの領域で注意すべきことは、吐き気な どに対する内関穴の有効性が示されているものの、 他経穴との比較を試みたという実験デザインが極 めて少ないため、内関穴に特有の効果があるとは 
表20. ヒト胃電図を指標とした鍼刺激の効果

\begin{tabular}{|c|c|c|c|c|}
\hline $\begin{array}{c}\text { 著者 } \\
\text { (発表年度) }\end{array}$ & 対象数 & 実験デザイン & 鍼の手法 & 結果 \\
\hline $\begin{array}{c}\text { 今井 } \\
(1996)\end{array}$ & $\begin{array}{l}\text { 健常人 } \\
\mathrm{N}=55\end{array}$ & $\begin{array}{l}\text { 鍼刺激前 } \\
\text { vs } \\
\text { 鍼刺激時 }\end{array}$ & $\begin{array}{l}\text { 腹部あるいは四肢へ } \\
\text { の雀啄 }\end{array}$ & $\begin{array}{l}\text { 腹部刺激で振幅減少、四肢刺激 } \\
\text { では変化なし。 }\end{array}$ \\
\hline $\begin{array}{l}\text { Xing W } \\
\text { (1998) }\end{array}$ & $\begin{array}{l}\text { 健常人 } \\
N=120\end{array}$ & $\begin{array}{c}\text { 鍼刺激前 } \\
\text { vs } \\
\text { 鍼刺激後 }\end{array}$ & $\begin{array}{l}\text { 足三里への } \\
\text { 置鍼、雀啄 }\end{array}$ & $\begin{array}{l}\text { 刺鍼手技によって胃電図はえ進 } \\
\text { あるいは抑制を示す。 }\end{array}$ \\
\hline $\begin{array}{l}\operatorname{Lin} X \\
(1997)\end{array}$ & $\begin{array}{l}\text { 健常人 } \\
N=9\end{array}$ & $\begin{array}{c}\text { 鍼刺激前 } \\
\text { vs } \\
\text { 鍼刺激後 }\end{array}$ & $\begin{array}{l}\text { 内関と足三里への } \\
\text { 銊通電 }\end{array}$ & $\begin{array}{l}\text { 鍼通電後に胃電図の周期が安定 } \\
\text { した。 }\end{array}$ \\
\hline $\begin{array}{l}\text { Chen R } \\
(1998)\end{array}$ & $\begin{array}{c}\text { NUD患者 } \\
\mathrm{N}=53\end{array}$ & $\begin{array}{l}\text { 鍼治療前 } \\
\text { vs } \\
\text { 鍼治療後 }\end{array}$ & 足三里、内関、胃俞 & $\begin{array}{l}\text { 胃電図の異常波形が減少し、愁 } \\
\text { 訴も改善。 }\end{array}$ \\
\hline
\end{tabular}

充分に示されていないのが現状である。内関穴を 使えば、成人の各種の吐き気に有効という結果が 示されているが、他部位に比べて内関穴が最も効 果的であるということが実証されているわけでは ないことに留意されたい。

さらに、実験的に乗り物酔い(motion sickness)の 状態を人為的に誘発させ、これに伴う吐き気・嘔 吐に対する内関穴への刺激効果についても、Evans 103）およびHu 104-105）によって報告されている（表 19）。Evansは被験者を回転イス（rotating chair）に 座らせ、吐き気を誘発した際に、内関穴へ acupressure（経穴圧迫刺激）を行った結果を報告 しており、一方、Huは被験者の回りに、黒と白の ストライプが入ったドラムを回転さすことで、視 覚性の乗り物酔い（optokinetic motion sickness）を 引き起こした場合のacupressureおよび通電の効果 を報告している。Evansは、 acupressure群とプラセ ボ群では有為な変化は得られなかったという結果 を提示しているが、Huは内関穴へのacupressureや 通電で、明らかに乗り物酔いの症状が軽減したと いう結果を報告している。現状では、この二者に よる 3 編の報告があるのみで、銊治療の効果につ いては未だ検討されていない。今後さらなる知見 の積み重ねが待たれるところであろう。

尚、吐き気・嘔吐に対する尒治療の知見に関し ては、私の知る限り現状では見受けられない。

\section{3. ヒトの消化器機能に対する鍼刺激の効果につ いて}

これまでにヒトの消化器機能に対する鍼刺激の 効果は、胃運動106-115)、胃酸分泌動態116-120)、胃 粘膜血流 ${ }^{121)}$ 、消化吸収能 ${ }^{122)}$ 、膵外分泌能 ${ }^{123,124)}$ 、 胆囊収縮 ${ }^{125)}$ 、肝血流量 ${ }^{126)}$ 、小腸 - 結腸運動 ${ }^{127-}$ 129)、内分泌動態130,131)、食道内圧, ${ }^{132,133)}$ 、などを 指標として、多くの実験研究が展開されてきた。 なかでも、胃機能に対する銊の効果については、 比較的多くの報告を見ることができ、すでに数編 の総説論文29,134,135) も発表されている。そこで、 本稿ではこれまでに行われてきた胃運動および胃 酸分泌動態に対する銊刺激の効果について焦点を 絞り、現在の研究の状況と問題点、およびこれら 実験研究の成果が臨床にどのようにフィードバッ クできるのかを考察する。

\section{1). 胃運動に及ぼす鍼刺激の効果（表20-22）}

銊尒研究の領域で胃運動を捉える指標として は、胃電図 68,106-112)、胃内視鏡113)、胃透視 114,115)、などが応用されている。なかでも近年 は胃電図による検討が多く報告されるようにな り、われわれもこの手法を用いて銊刺激の作用 と機序を検討してきた116-109)。簡単に胃電図に ついて解説すると、胃には運動に先立つ電気活 動が存在し、この電位は約 1 分間に 3 回の周期 で胃大弯側上部から幽門側に伝播することが知 
表21．胃内視鏡を用いた検討

\begin{tabular}{|c|c|c|c|c|}
\hline $\begin{array}{c}\text { 著者 } \\
\text { (発表年度) }\end{array}$ & 対象数 & 実験デザイン & 鍼の手法 & 結果 \\
\hline $\begin{array}{l}\text { Yuan. } \\
\text { (1985) }\end{array}$ & $N=50$ & $\begin{array}{l}\text { 対照群 } \\
\text { vs } \\
\text { 鍼刺激群 } \\
\text { (RCT) }\end{array}$ & 足三里に鍼通電 & $\begin{array}{l}\text { 対照群に比べて大きく胃運動が } \\
\text { 増加あるいは減少したものが認 } \\
\text { められた }\end{array}$ \\
\hline
\end{tabular}

表22. 胃透視を用いた検討

\begin{tabular}{|c|c|c|l|l|}
\hline $\begin{array}{c}\text { 著者 } \\
\text { (発表年度) }\end{array}$ & 対象数 & 実験デザイン & 鍼の手法 & 結果 \\
\hline \hline $\begin{array}{c}\text { Jiang. } \\
(1986)\end{array}$ & $\mathrm{N}=90$ & $\begin{array}{c}\text { 対照群 } \\
\text { vs } \\
\text { 銊刺激群 }\end{array}$ & 耳の空腹穴に置鍼 & 胃が弛緩 \\
\hline $\begin{array}{c}\text { 愛知 } \\
(1997)\end{array}$ & $\mathrm{N}=3$ & 症例 & $\begin{array}{c}\text { 足三里に単刺、置鍼 } \\
\text { (阿是穴も使用) }\end{array}$ & $\begin{array}{c}\text { 迷走神経遮断剂投与後に停止し } \\
\text { た胃の蠕動が鍼刺激で出現した }\end{array}$ \\
\hline
\end{tabular}

られている136)。胃電図の出現周期は胃運動の サイクルを調律し、振幅は胃運動の強さを反映 するとされ、実際に胃全摘患者では胃電図が消 失し137)、また胃運動の抑制を引き起こす硫酸 アトロピンの投与などで胃電図の振幅も減弱す る138)ことが確認されている。本法は、腹部に 表面電極を装着するだけで簡単に、且つ非侵襲 的に測定できるため、他の胃運動能を測定する 手法に比して、鍼炎の効果を評価するには適し た手法といえよう。そして、この胃電図を指標 とした銊刺激の効果に関する検討が95年以降、 除々に増えている傾向にある（表20）。今井109） は健常人 55 名を対象に、鍼刺激が胃電図に及ほ す反射性反応を検討したところ、腹部への鍼刺 激で胃電困の振幅が減少することを明らかにし、 この機序としては交感神経を遠心性に介してい ることを示した。この結果は、Satoら ${ }^{39)}$ が胃内 圧を指標に動物実験で示した結果と同様な反射 経路がヒトでも存在し、胃運動に対する鍼刺激 の作用機序には体性一内臓反射が大きく関与し ていることを支持するものである。一方、Xing 110)は足三里への置鍼や雀啄を行ったところ、 刺銊手技によって結果が異なることを報告して いる。さらに、Lin ${ }^{111)} と$ Chen ${ }^{68)}$ は、より臨床 的な検討として、いづれも鍼刺激を施行するこ とで胃電図の正常波形の割合が増加することを
示した。これまでに、自律機能障害を伴う各種 疾患や、吐き気・嘔吐がある時、また腹部外科 手術後などでは、胃電図の波形が乱れる事が知 られており 139-141)、LinとChenの報告は、このよ うな場合を想定して鍼で胃電図の乱れを整えら れるかどうかを検討したものである。特に、 Chen ${ }^{68)}$ は非潰瘍性胃腸症患者 (non-ulcer dyspepsia:NUD）を対象に検討し、鍼治療後に は胃電図の異常波形が減少し、患者の愁訴も改 善した事を示している。

そして、胃内視鏡や胃透視などを用いて、実 際にヒトの胃運動を観察しながら鍼刺激の効果 を検討した報告は、少なくとも 3 編に見ること ができる113-115）(表21、表22）。胃内視鏡で胃運 動を観察して足三里への鍼通電の効果を検討し たYuan ${ }^{113)}$ は、対象群に比べ鍼通電群では胃運 動が著しく増加あるいは減少したものを認めた と報告している（表21）。さらに、X線下で胃透 視をしながら、鍼の作用を検討した報告は、 Jiang ${ }^{114)}$ が耳の空腹穴への置鍼で胃の驰緩が得 られたという結果を述べて㧍り、また愛知115) は少ない症例数ではあるが迷走神経遮断剂投与 後に停止した胃の蠕動が足三里などへ鍼を行う と再度出現し始めたという経験を報告している (表22)。

これらのヒトを対象とした報告をまとめると、 
表23. 胃酸分泌に対する鍼刺激の効果

\begin{tabular}{|c|c|c|c|c|}
\hline $\begin{array}{c}\text { 著者 } \\
\text { (発表年度) }\end{array}$ & 対象数 & 実験デザイン & 鍼の手法 & 結果 \\
\hline $\begin{array}{l}\text { Sodipo } \\
(1979)\end{array}$ & $\begin{array}{c}\text { 胃十二指腸潰瘍患者 } \\
\mathrm{N}=10 \\
\mathrm{NUD} \text { 患者 } \\
\mathrm{N}=4\end{array}$ & 治療前後で比較 & $\begin{array}{l}\text { 腹部と下肢の経穴に } \\
\text { 鍼通電群 }\end{array}$ & 酸分泌量の低下 \\
\hline $\begin{array}{c}\text { 池内 } \\
(1985)\end{array}$ & $\begin{array}{l}\text { 健常人 } \\
\mathrm{N}=11\end{array}$ & $\begin{array}{l}\text { 対照群 } \\
\text { vs } \\
\text { 鍼通電群 }\end{array}$ & $\begin{array}{l}\text { 足三里あるいは陽陵 } \\
\text { 泉に鍼通電 }\end{array}$ & $\begin{array}{l}\text { 足三里では酸分泌増加、陽陵泉 } \\
\text { では低下 }\end{array}$ \\
\hline $\begin{array}{l}\text { 野口 } \\
(1989)\end{array}$ & $\begin{array}{l}\text { 健常人 } \\
\mathrm{N}=38\end{array}$ & 反復実験 & $\begin{array}{l}\text { 体幹部あるいは下肢 } \\
\text { に鍼通電 }\end{array}$ & $\begin{array}{l}\text { 足三里、解簛への刺激で基礎酸 } \\
\text { 分泌量が低下 }\end{array}$ \\
\hline $\begin{array}{l}\text { Tougas } \\
(1992)\end{array}$ & $\begin{array}{l}\text { 健常人 } \\
N=38\end{array}$ & $\begin{array}{c}\text { 対照群 (プラセボ) } \\
\text { vs } \\
\text { 鍼通電群 }\end{array}$ & 足三里に鍼通電 & $\begin{array}{l}\text { 基礎酸分泌が低下し、またsham } \\
\text { feeding（偽食事負荷）で増加す } \\
\text { るげき酸分泌も抑制された }\end{array}$ \\
\hline $\begin{array}{l}\operatorname{Lux} \\
(1994)\end{array}$ & $\begin{array}{l}\text { 健常人 } \\
N=8\end{array}$ & $\begin{array}{c}\text { 対照群 (プラセボ) } \\
\text { Vs } \\
\text { 鍼通電群 }\end{array}$ & $\begin{array}{l}\text { 足三里と胃俞に鍼通 } \\
\text { 電 }\end{array}$ & $\begin{array}{l}\text { sham feeding (偽食事負荷) で } \\
\text { 増加するべき酸分泌が抑制され } \\
\text { た }\end{array}$ \\
\hline
\end{tabular}

（1）腹部へ鍼刺激をしている最中には胃電図の 振幅が減少し、これは胃内圧を指標とした動物 実験の結果と一致するものである。

(2) 銊刺激などにより胃電図の周期が安定する (異常波形が減少する) という一致した見解が $\mathrm{Lin}^{111)}$ 、Chan ${ }^{68)} 、 \mathrm{Hu}^{104,105)}$ の報告から示され、 不整な胃運動を引き起こす症状に対して鍼治療 は有効となる可能性があることが示㖫されてい る。

（3）胃電図および胃内視鏡、胃透視を用いた結 果を照合する限りでは、鍼刺激による胃運動へ の影響は未だ整合性が得られない状況にある。 今後この領域における更なる知見の積み重ねが 待たれるところであろう。

2 ）ヒト胃酸分泌に対する銊刺激の効果（表23）

ヒトの胃酸分泌動態に及ほすす銊の効果を最初 に報告したのは、ナイジェリアのSodipoによる 1979年の論文 ${ }^{10)}$ が最初と思われる。この論文 は、十二指腸潰瘍患者と非潰瘍性胃腸症患者 （NUD）の 2 群を対象に、腹部や下肢へ鍼通電 を行ったところ、酸分泌量の低下と腹痛などの 症状の緩和が十二指腸潰瘍患者群で得られたと
報告しており、鍼治療による酸分泌の抑制が十 二指腸潰瘍患者の症状の改善に関与しているこ とを示している。

そして、現在までに健常人を対象とした実験 研究を、欧米ではTougas ${ }^{119)}$ およびLux ${ }^{120)}$ が、

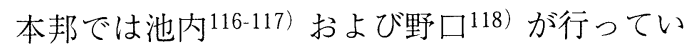
る。Tougas ${ }^{119)}$ は足三里に鍼通電を、Lux ${ }^{120)}$ は 足三里と胃愈穴に鍼通電を行ったところ、いづ れも sham feeding (偽食事負荷) で本来なら増 加するべき酸分泌量が、プラセボ群に比して鍼 通電群で抑制されたことを報告した。特にTougas は、平常時の酸分泌量（基礎酸分泌量）も鍼通 電群で抑制したことも確認しているが、この報

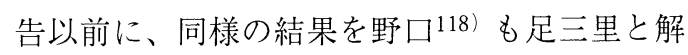
彩穴への銊通電刺激で得られることを報告して いる。

これらの結果を展望すると、ヒトの胃酸分泌 に対する銊の効果は、（1）鍼通電での検討がな され、（2）胃酸分泌を低下さす、という結果が いづれの研究においても共通した事項となって いる。そのため、胃・十二指腸潰瘍などの酸分 泌の元進を伴うような疾患に対して鍼治療（鍼 通電）を対症的な治療方法として試みる価值は、 
充分にあると言えるのではないかと思われる。 だが、どの部位への刺鍼が最も効果的なのかは、 これらの内容からは不明である。池内ら 116,117$)$ のように他報告とは異なり、足三里穴への鍼通 電では酸分泌が増加する一方で、陽陵泉穴への 鍼通電では酸分泌の低下が得られるという、経 穴の穴性による効果の違いを考察している報告 もある。しかし、ここに揚げた報告の多くでは 足三里穴を使用して、酸分泌の低下を得ている ため、酸分泌充進を伴うような疾患に対しては、 この部位への刺銊を選択するのが現状では妥当 と考えられるのではないだろうか。今後、この ような研究の現状を踏まえた上で、胃・十二指 腸潰瘍などに対する銊治療の実験的研究と臨床 試験がより広く展開され、鍼治療が臨床的によ り価值のあるものとして位置付けられればと願 うところである。

\section{4. 小括}

(1) 消化器疾患に対する鍼尒の効果については、 体系的な検討が行われてなく、各疾患に対する 鍼尒の有効性は判然としていないのが現状であ った。今後より精度の高い臨床試験を経て銊尒 の有効性を吟味する必要があろう。

（2）消化器症状の一つである吐気・嘔吐に関し ては、手術後早期に出現する症状、妊娠時の悪 阻、化学療法時の症状に対しては、内関穴への 鍼治療やacupressureが有効であるという結論が 支持されているが、その作用機序については判 然としていない。そして一方では、小児の吐き 気・嘔吐に対しては、その効果が得られないと いう結果が複数の報告で一致してもいる。この 領域においては、多くの臨床試験が行われ、鍼 治療の有効性が示された。今後は、作用機序の 解明も視野に入れ研究を展開さす必要があるの ではないだろうか。

（3）胃機能については、鍼刺激により胃電図の 周期が安定するという一致した見解が LinとChan、 $\mathrm{Hu}$ の報告から示された。このことは、不整な胃 運動を引き起こす症状に対して鍼治療は有効と なる可能性があるものと思われた。また、体性内臓反射の視点からは、腹部への鍼刺激で胃電
図の振幅が減少したことから胃運動の減弱を引 き起こすという可能性が示され、これと類似し た結果はラットを用いた基礎研究でも見る事が できる。鍼刺激の作用機序のひとつとして、体 性-内臓反射は重要なところであろう。だが、全 般的にヒトの胃運動そのものを記録して、銊尒 の効果を確認したという報告は極めて少なく、 今後の研究の積み重ねが待たれるところであろ う。

（4）ヒトの胃酸分泌に対する鍼刺激の効果は、 鍼通電での検討が多くなされており、胃酸分泌 を低下さすという結果が現状では支持されるも のと思われる。このことは、胃潰瘍などの酸分 泌の克進を伴うような疾患に対して対症療法と して鍼治療を応用することは、妥当であること を意味している。だが、どの経穴への刺銊が最 も効果的なのかは、従来の報告からは明らかに なっていない。しかし、多くの報告で足三里穴 を用いている点が共通しているため、酸分泌の 抑制を期待するならば、この部位への刺銊を第 一に選択しても良いのではないだろうか。

\section{おわりに}

本稿の内容の一部は、すでに本誌に発表された ものであるが142)、今回のセミナーのために調査 収集された文献の具体的内容をきちんとした形で 残すために、編集部に依頼して総説の形として改 めてまとめたものである。今回のテーマは「内蔵 痛と消化器関連の疾患・諸症状に対する鍼治療」 に関するものであった。このテーマが選ばれた理 由は、我が国の銊尒の臨床で古くより治療対象と されてきており、また優れた研究が我が国におい て行われてきたこと、さらにはNIHの報告におい ても術後の吐き気に対する鍼の効果を比較的エビ デンスがあるとした取り上げられたこと、などが 挙げられる1)。

今回の総説はあくまでも鍼尒研究の途中経過を 紹介したに過ぎない。本テーマに関する基礎・臨 床研究が今後ますます発展して、確たるエビデン スをさらに積み重ねていくことが強く求められて いるといえよう。また、このような形でセミナー の成果がまとめられ、これからもテーマと報告者 
を選んで継続的に行われていくことは、我が国の 研究業績をきちんとした形で残すためにも極めて 有意義な作業であると考えるものである。

\section{引用文献}

1) 川喜田健司, 立梞廷族, 中村行雄, 渡仲三, 米国国立衛生研究所(NIH) 合意形成声明書, 鍼修正草案 $(1997 / 11 / 5)$. 医道の日本。 1998;643:16-25

2 ) 川喜田健司, 立杰廷族, 中村行雄, 渡仲三, NIH合意形成声明の最終版について. 医道の 日本. 1998;646:90-3.

3 ) Jiang R. Analgesic effect of acupuncture on acute intestinal colic in 190 cases. J Tradit Chin Med. 1990;10(1): 20-1.

4 ) 岩昌宏, 工藤大作, 渡邊勝之, 甲田久士, 山 川緑, 石丸圭荘, 篠原昭二, 畑幸樹, 鈴山博 司，咲田雅一，イレウス患者に対する銊炎治 療一腸蠕動に及ぼす鍼治療の効果一, 明治鍼 尒医学. 1989;5:89-94.

5 ) No authors listed. Treatment of acute intestinal obstruction by combined traditional Chinese and western medicine: a report of 1,006 cases. Chin Med J (Engl). 1978; 4(6):472-5.

6 ) Ballegaard S, Christophersen S J, Dawids S G, Hesse J, Olsen $N$ V. Acupuncture and transcutaneous electric nerve stimulation in the treatment of pain associated with chronic pancreatitis: A randomized study. Scand J Gastroenterol. 1985;20(10):1249-54.

7 ) Zhang J. Treatment with acupuncture at zusanli (St 36) for epigastric pain in the elderly. J Tradit Chin Med. 1992;12(3):178-9.

8 ) Li S R, You S Z, Zhang S L. The research of a new way to apply laser acupuncture. Chen Tzu Yen Chiu. 1988;13(3):179-83.

9 ) Debreceni L, Denes L. Acupuncture treatment for duodenal ulcer. Acupunct Electrother Res. 1988; 13(2-3):105-8.

10) Sodipo J O, Falaiye J M. Acupuncture and gastric acid studies. Am J Chin Med. 1979;7(4):356-61.

11) Eriksson M B, Sjolund B H, Nielzen S. Long term results of peripheral conditioning stimulation as an analgesic measure in chronic pain. Pain. 1979;6(3):335-47.

12) Sjogren $P$, Banning A M, Jensen $N$ H, Jensen $M$, Klee. Management of cancer pain in Denmark: a nationwide questionnaire. Pain. 1996;64(3):51925.

13) Chen H. Recent studies on auriculoacupuncture and its mechanism. J Tradit Chin Med. 1993; 13(2):129-43.

14) Zheng X L, Chen C, Wu X Z. Acupuncture therapy in acute abdomen. Am J Chin Med. 1985; 13(1-4):127-31.

15) Huang Z, Liu N, Zhong S, Lu J, Zhang N. The role of nucleus tractus solitarii (NTS) in acupuncture inhibition of visceral-somatic reflex. Chen Tzu Yen Chiu. 1991;16(1):43-7.

16) Du H J, Chao Y F. Localization of central structures involved in descending inhibitory effect of acupuncture on viscero-somatic reflex discharges. Sci Sin. 1976;19(1):137-48.

17) Sumiya E, Kawakita K. Inhibitory effects of acupuncture manipulation and focal electrical stimulation of the nucleus submedius on a viscerosomatic reflex in anesthetized rats. Jpn J Physiol. 1997;47(1):121-30

18) Sun M, Li Y, Zhang J, Bian J. Effects of noxious stimuli on the discharges of pain-excitation neurons and pain-inhibition neurons in the nucleus ventralis posterolalis of thalamus in the rat and a modulating action of electroacupuncture on its electric activities. Chen Tzu Yen Chiu. 1991;16(1):19-22.

19) Gong S, Yin W P, Yin Q Z. Involvement of vasopressinergic neurons of paraventricular nucleus in the electroacupuncture-induced inhibition of experimental visceral pain in rats. Sheng Li Hsueh Pao. 1992;44(5):434-41.

20) Luo D S, Cheng J S. Role of the dorsal hippocampus in electroacupuncture inhibition of visceral nociceptive responses in the conscious rabbit. Chen Tzu Yen Chiu. 1987;12(3):196-201. 
21) Shu J, Li K Y, Huang D K. The central effect of electro-acupuncture analgesia on visceral pain of rats: a study using the [3H] 2-deoxyglucose method. Acupunct Electrother Res. 1994;19(2-3): $107-17$

22) Guoxi T. The action of the visceronociceptive neurons in the posterior group of thalamic nuclei: possible mechanism of acupuncture analgesia on visceral pain. Kitasato Arch Exp Med. 1991; 64(1):43-55.

23) Cai $B$, Huang $X$, Wang G, Mo W. Potentiation of electroacupuncture analgesia on visceral pain by metoclopramide and its mechanism. Chen Tzu Yen Chiu. 1994;19(1):66, 70, 74.

24) Zhang J M, Guo L N, Chen P X. The effect of electro-acupuncture of "neiguan" acupoint on cortical potential evoked by stimulating C-fibers of splanchnic nerve. Chen Tzu Yen Chiu. 1989; 14(4):410-3.

25) Yang J, Zhao R, Yuan J, Chen G, Zhang L, Yu M, Lu A, Zhang Z. The experimental study of prevention and treatment of the side-effects of chemotherapy with acupuncture. Chen Tzu Yen Chiu. 1994;19(1):75-8.

26) Andreev B V, Vasil'ev IuN, Ignatov IuD, Kachan A T, Bogdanov N N. Effect of electroacupuncture on signs of emotional stress caused by pain. Biull Eksp Biol Med. 1981;91(1):18-20.

27) Jin S R, Huang Z S. A study of the specificity of the depressing action of the "zusanli" acupoint in visceral pain of conscious cats. Chen Tzu Yen Chiu. 1987;12(1):73-6.

28) Tang D A. Advances in research on the mechanism of acupuncture and moxibustion. Chen Tzu Yen Chiu. 1987; 12(4):278-84.

29) Li,Y. et al., The effect of acupuncture on gastrointestinal function and disorders. The American Journal of Gastroenterology. 1992; 87(10):1372-81.

30) Brom,M., The effect of acupuncture on salivary flow rates in patients with xerostomia. Oral. Surg. Oral. Med. Oral. Patho.1992;293-8.
31) Dawidson,I. et al., The influence of acupuncture on salivary flow rates in healthy subjects. Journal of Oral Rehabilitation. 1997;24:204-8.

32) Dawidson,I. et al., Sensory stimulation (acupuncture) increases the release of vasoactive intenstinak polypeptide in the saliva of xerostomia sufferers. Neuropeptides. 1998; $32(2): 543-8$.

33) Dawidson,I. et al., Sensory stimulation (acupuncture) increases the release of calcitonin geno-related peptide in the saliva of xerostomia sufferers. Neuropeptides. 1999;33(3):244-250.

34）小俣浩, 他. シェーグレン症候群 (sjs), 患 者の乾燥症状に対する銊治療効果. 日本温泉 気候物理医学会. 2000;63(2):79-90.

35) Sato, A. et al., Changes in gastric motility produced by nociceptive stimulation of the skin in rats. Brain research. 1975;87:151-9.

36) Kametani, H. et al. , Neural mechanisms of reflex facilitation and inhibition of gastric motility to stimulation of various skin areas in rats. Journal of Physiology. 1979;294;407-18.

37）森秀太郎, 鍼刺激と胃体運動一鍼の作用機序 に関する研究一。日鍼尒誌。1978;27(2):12731.

38) Kudo, T. et al., Depression of gastric contraction by stimulation of BL-19 (Weiyu) acupoints in dogs. Am.J.Chi.Med. 1991;19(3):241-5.

39) Sato, A. et al., Neural mechanisms of the reflex inhibition and excitation of gastric motility elicited by acupuncture-like stimulation in anesthetized rats. Neurosci.Res. 1993;18:53-62.

40）山口真二郎, 他, 麻酔ラットの胃運動に及ほ す鍼通電刺激の効果. 自律神経. 1996;33(1): 39-45.

41) Zhou, L. et al., Electic acupuncture stimulates non-parietal cell secretion of the stomach in dog. Life Science. 1984;34:2233-8.

42) Jin, H., et al., Inhibition of acid secretion by electrical acupuncture is mediated via betaendorphin and somatostatine. Am J. Physiol.. 1996;G524-30. 
43）恒健生 et al. 電針 “足三里” 対大白鼠胃酸分 泌的影響. 上海中医葯卆志. 1986;4:44-5.

44）野口栄太郎。ラット胃酸分泌に及ぼす銊刺激 の効果. 埼玉医学会誌. 1991;18(1):33-46.

45) Noguchi, E. et al., Increases on gastric acidity in response to electroacupuncture stimulation of the hindlimb of anesthetized rats. Japan Journal of Physiology. 1996;46:53-8.

46) Stux, G., Pomeranz, B.. Basics of Acupuncture. Fourth Edition. Berlin Heidelberg. SpringerVergan. 1998:29-34

47）本郷孝博.酶酸・焼灼潰瘍（ラット胃）に対 する鍼刺激の治療効果 (2). 全日本鍼炎学会 雑誌. 1982;32(2):83-7.

48）本郷孝博, 松本 勅, 篠原昭二. 酢酸 - 焼灼 潰瘍（ラット胃）に対する鍼刺激の治療効果 (1)。全日本銊多学会雑誌. 1982;31(3):232-7.

49）本郷孝博. 水素クリアランス法による血流量 測定の銊尒医学への応用 (第 1 報). 日本東 洋医学雑誌. 1983;34(2):31-98.

50) 本郷孝博, 松本 勅. 水浴ラットのストレス 胃潰瘍発生に対する鍼刺激の予防効果. 自律 神経䧱誌。1981;27(4):400-4

51) Sato, Y. et al., Changes in duodenal motility produced by noxious mechanical stimulation of the skin in rats. Neurosci. Lett., 1976;2:189-93.

52) Koizumi, K. et al., Role of somatic afferents in autonomic system control of the intestinal motility. Brain Res. 1976;182:85-97.

53）藤井秀二，他，小児銊ノ腸運動二及又影響 (実験的研究). 大阪医学会誌. 1929;28:202932.

54) Iwa, H. et al., Effects of acupuncture and moxibustion on intestinal motility in mice. Am.J.Chin.Med. 1994;22(2):119-25.

55）野口栄太郎, 他. 麻酔ラットの十二指腸運動 に対する銊尒刺激の効果. 自律神経. 2001;38 (2): 176 .

56) Hep A, Dolina J, Dite P, Plottova Z, Valek V, Kala Z, Prasek J. : Restoration of propulsive peristalsis of the esophagus in achalasia. Hepatogastroenterology. 2000;47(35):1203-4.
57) Guelrud M, Rossiter A, Souney PF, Sulbaran M.:Transcutaneous electrical nerve stimulation decreases lower esophageal sphincter pressure in patients with achalasia.Dig Dis Sci. 1991; 36(8):1029-33.

58) Mearin F, Zacchi P, Armengol JR, Vilardell M, Malagelada JR. :Effect of transcutaneous nerve stimulation on esophageal motility in patients with achalasia and scleroderma.Scand J Gastroenterol. 1990;25(10):1018-23.

59) Kaada B. : Successful treatment of esophageal dysmotility and Raynaud's phenomenon in systemic sclerosis and achalasia by transcutaneous nerve stimulation. Increase in plasma VIP concentration.Scand J Gastroenterol. 1987;22(9):1137-46.

60) Xu P., Tian C. :Clinical observation on treatment of acute epigastralgia by puncturing Liangqiu and Weishu acupoints.International J Clinic Acupuncture. 1991;2(2):127-30.

61) Borjesson M, Pilhall M, Eliasson T, Norssell H, Mannheimer $\mathrm{C}$, RolnyP.:Esophageal visceral pain sensitivity: effects of TENS and correlation with manometric findings. Dig Dis Sci. 1998;43(8): 1621-8.

62) Ba Y, Xiang N, Tan Z, Zhang Y, Tan Y.: Treatment of epigastralgia by external application of huweigao at shenque point. J Tradit Chin Med. 1999;19(3):214-7.

63) Ishizaki N., Kiyofuji S., Egawa M., et. al. : A case of gastric ulcer effectively treated by acupuncture. Bulletin of Meiji College of Oriental Med. 1988;4:99-104.

64) Debreceni L, Denes L.: Acupuncture treatment for duodenal ulcer. Acupunct Electrother Res. 1988;13(2-3):105-8.

65) Chen Z.: Treatment of chronic gastritis with acupuncture. J Tradit Chin Med. 1994;14(3):2335.

66) Matsumoto, T., Hayes, MF.: Acupuncture, electric phenomenon of the skin, and postvagotomy gastrointestinsl atony. Am J 
Surg. 1973;125:176-80.

67) Matsumoto T, Hayes MF, DeLaurentis D,Miyata M. : Evaluation of acupuncture in management of gastrointestinal atony following vagotomy.Surg Forum. 1972;23(0):401-2.

68) Chen R, Kang M. :Observation on frequency spectrum of electrogastrogram (EGG) in acupuncture treatment of functional dyspepsia. J Tradit Chin Med. 1998;18(3):184-7.

69）王 勇，智慧。針刺特定穴治療非潰瘍性消化 不良65例臨床観察．針刺研究．2000;25:5961.

70) Chen, J., Carr, I., Mayberry, JF: The role of acupuncture in treatment of irritable bowel syndrome. A piloy study. HepatoGastroenterology. 1997;44:1328-30.

71) Fan YK, Zhang CC.: 20 years' acupuncture in 461 acute appendicitis cases. Chin Med J. 1983 ;96(7):491-4

72) Li ZS.: Observation of curative effects of emergency acupuncture treatment in 172 cases of infantile toxic intestinal paralysis. J Tradit Chin Med. 1987;7(3):209-10.

73) Jiang R.: Analgesic effect of acupuncture on acute intestinal colic in 190 cases. J Tradit Chin Med. 1990;10(1):20-1.

74) Zhang Y, Zhang L, Yang H, Zhang H, Zhu Y.: 1291 cases of cholelithiasis treated with electric shock on otoacupoints. J Tradit Chin Med. 1991;11(2):101-9.

75) Zhang R, Ma SZ, Zhang TQ.: The effect of auricular-plaster therapy on gal lstone expulsion and on expansion-contraction function of the biliary system--a clinical analysis of 57 cases. J Tradit Chin Med. 1986;6(4):263-6.

76）七堂利幸, 有地滋, 鴨原丈一, 森 悦子, 米山 義. 慢性肝疾患に対する尒効果．日鍼 尒誌. 1980;29(3):56-71.

77）戸田静男，樋口良孝，有地 滋。肝障害の八 リ効果. 自律神経雑誌. 1978;25:87-90.

78）猪狩知之，木村好弘，下村壮介，林 信治, 坂本浩二。慢性肝障害に対する鍼炎治療効果
の検討．全鍼炎誌．1982;32(2):34-9.

79）黒野保三：慢性肝障害に対する銊治療の検討 （その3）。全日本鍼多学会雑誌，1986;36(3): 178-82.

80) Ballegaard S, Christophersen SJ, Dawids SG, Hesse J, Olsen NV.:Acupuncture and transcutaneous electric nerve stimulation in the treatment of pain associated with chronic pancreatitis. A randomized study.Scand J Gastroenterol. 1985;20(10):1249-54.

81) Diehl DL: .Acupuncture for gastrointestinal and hepatobiliary disorders.J Altern Complement Med. 1999;5(1):27-45.

82) Acupuncture. NIH Consensus Statement 15:(5), November 3-5, 1997.

83) Fry, ENS: Acupressure and postoperative vomiting. Anaesthesia . 1986;41:661-2.

84) Dundee JW, Chestnutt WN, Ghaly RG, Lynas AG.:Traditional Chinese acupuncture: a potentially useful antiemetic?Br Med J (Clin Res Ed). 1986;293(6547):583-4.

85) Dundee JW.Milligan KR: Acupuncture as antiemetic.Br Med J.1988;296(9):135.

86) Dundee JW, Ghaly RG, Bill KM, Chestnutt WN, Fitzpatrick KT, Lynas AG.: Effect of stimulation of the P6 antiemetic point on postoperative nausea and vomiting. Br J Anaesth. 1989; 63(5):612-8

87) Dundee JW, McMillan CM.: Clinical uses of P6 acupuncture antiemesis.Acupunct Electrother Res. 1990;15(3-4):211-5. Review.

88) Ghaly RG, Fitzpatrick KT, Dundee JW.: Antiemetic studies with traditional Chinese acupuncture. A comparison of manual needling with electrical stimulation and commonly used antiemetics.Anaesthesia. 1987;42(10):1108-10.

89) Wang B, Tang J, White PF, Naruse R, Sloninsky A, Kariger R, Gold J,Wender RH.: Effect of the intensity of transcutaneous acupoint electrical stimulation on the postoperative analgesic requirement.Anesth Analg. 1997;85(2):406-13.

90) al-Sadi M, Newman B, Julious SA.40: Acu- 
puncture in the prevention of postoperative nausea and vomiting. Anaesthesia. 1997;52(7): 658-61.

91) Chen L, Tang J, White PF,: Sloninsky A, Wender RH, Naruse R, Kariger R.The effect of location of transcutaneous electrical nerve stimulation onpostoperative opioid analgesic requirement: acupoint versus nonacupoint stimulation. Anesth Analg. 1998;87(5):1129-34.

92) Lee A, Done ML.: The use of nonpharmacologic techniques to prevent postoperative nausea and vomiting: a meta-analysis. Anesth Analg. 1999;88(6):1362-9.

93) Vickers AJ.: Can acupuncture have specific effects on health? A systematic review of acupuncture antiemesis trials. J R Soc Med. 1996;89(6):303-11. Review

94) Belluomini J, Litt RC, Lee KA, Katz M.: Acupressure for nausea and vomiting of pregnancy: a randomized, blinded study. Obstet Gynecol. 1994;84(2):245-8.

95) Aikins Murphy P.: Alternative therapies for nausea and vomiting of pregnancy. Obstet Gynecol. 1998;91(1):149-55.Review.

96) Allaire AD, Moos MK, Wells SR.: Complementary and alternative medicine in pregnancy: a survey of North Carolina certified nursemidwives. Obstet Gynecol. 2000;95(1):19-23.

97) Dundee JW, Ghaly RG, Fitzpatrick KT, Lynch GA, Abram WP.: Acupuncture to prevent cisplatin-associated vomiting. Lancet. 1987 May 9;1 (8541):1083.

98) Dundee JW, Ghaly RG, Fitzpatrick KT, Abram WP, Lynch GA.: prophylaxis of cancer chemotherapy-induced sickness.J R Soc Med. 1989;82(5):268-71.

99) Dundee JW, Yang J.: Prolongation of the antiemetic action of P6 acupuncture by acupressure in patients having cancer chemotherapy. J R Soc Med. 1990;83(6):360-2.

100) Dundee JW, McMillan C.: Positive evidence for P6 acupuncture antiemesis.Postgrad Med J.
1991;67(787):417-22. Review.

101) Shen J, Wenger N, Glaspy J, Hays RD, Albert PS, Choi C, Shekelle PG.: Electroacupuncture for control of myeloablative chemotherapy-induced emesis: A randomized controlled trial. JAMA. 2000 Dec 6;284(21):2755-61.

102）井上悦子，小島賢久，七堂利幸。吐き気· 嘔吐の必要治療数(NNT)。全日本銊尒学会雑 誌. 2000;50(2):345.

103) Warwick-Evans LA, Masters IJ, Redstone SB.: A double-blind placebo controlled evaluation of acupressure in the treatment of motion sickness. Space Environ Med. 1991; 62(8):776-8.

104) Hu S, Stern RM, Koch KL.: Electrical acustimulation relieves vection-induced motion sickness. Gastroenterology. 1992;102(6):1854-8.

105) $\mathrm{Hu}$ S, Stritzel R, Chandler A, Stern RM. :P6 acupressure reduces symptoms of vectioninduced motion sickness. Aviat Space Environ Med.. 1995;66(7):631-4.

106）今井賢治，小高ますみ，樋口淳一，吉井智 子, 渡邊清剛, 岩 昌宏, 石丸圭荘, 篠原昭 二, 畑 幸樹, 咲田雅一. 経皮的胃電気活動 記録（Electrogastrography:EGG）と鍼尒（第 1 報)。 その基礎的および臨床的研究. 明治 銊尒医学. 1991;9:33-9.

107）今井賢治. Electrogastrography (EGG)を指標 とした鍼刺激の効果および外科領域における その応用に関する研究. 明治鍼尒医学. 1993; 12:45-54.

108）今井賢治, 石丸圭荘, 岩昌宏, 佐々木定之, 咲田雅一、ヒト腹部への鍼刺激が引き起こす 胃電図（Electrogastrography:EGG）の抑制反 応. 日本自律神経学会雑誌. 1996;33(2):1349.

109）今井賢治. 鍼刺激が引き起こすヒトの胃電 図，瞬時心拍数および交感神経性皮膚反応の 変化とその機序に関する研究. 明治鍼尒医学. 1996;19:45-55.

110) Xing, W., LI, Q.: Effects of differnt manipulations of acupuncture on electrical activity of stomach in humans. J Tradit Chine 
Med. 1998;18(1):39-42.

111) Lin $X$, Liang J, Ren J, Mu F, Zhang M, Chen JD.: Electrical stimulation of acupuncture points enhances gastric myoelectrical activity in humans. Am J Gastroenterol. 1997;92(9):152730.

112）蔡国偉, 楊 毅, 梁書忠. 胃潰瘍患者の胃 電図に与える耳胃点電気針刺の影響。中西医 結合. 1995;6(2):43-5.

113) Yuan CX, Zhu J, Zhing LX, et al.: Gastroscopic observation of the effect of acupuncture on gastric motility. Jiangxi J Chin Trad Med. 1985;3:33-4.

114) Jiang JH.: Ear acupuncture for hypotonia in gastrointestinal examination. AJR. 1986;147: 862. (letter)

115）愛知政則，川瀬勝志. 足三里穴の胃の蠕動 運動に及ぼす影響。体性一胃反射の実験。医 道の日本. 1997;641:56-60.

116）池内隆治, 長谷川汪，田和宗徳。胃液分泌 に及ほす鍼尒刺激の影響. 全日本鍼尒学会雑 誌. 1982;31(3):238-242.

117）池内隆治，長谷川汪．胃液分泌に及ぼす鍼 炎刺激の影響（第 2 報）。明治銊尒医学. 1985;1:1-7.

118）野口栄太郎，芹澤勝助，佐藤登志郎：鍼刺 激の胃酸分泌機能に及ぼす影響。日温気物医 誌. 1989;52(3):146-58.

119) Tougas G, Yuan LY, Radamaker JW, Chiverton SG, Hunt RH.: Effect of acupuncture on gastric acid secretion in healthy male volunteers. Dig Dis Sci. 1992;37(10):1576-82.

120) Lux G, Hagel J, Backer P, Backer G, Vogl R, Ruppin H, Domschke S, Domschke W.: Acupuncture inhibits vagal gastric acid secretion stimulated by sham feeding in healthy subjects.Gut. 1994;35(8):1026-9.

121) Ishizaki N., Yamamura Y., Seyama F., et. al.: Effect of acupuncture stimulation on gastric mucosal microcirculation.Bulletin of Meiji College of Oriental Med. 1992;11:1-9.

122）小高ますみ, 渡邊清剛, 樋口淳一, 吉井智
子, 今井賢治, 岩 昌宏, 石丸圭荘, 篠原昭 二, 畑 幸樹, 咲田雅一. 脾虚証に対する銊 治療効果と消化吸収能の関連性について, 明 治銊尒医学. 1992;10:11-8.

123）野口栄太郎, 佐藤登志郎。鍼刺激の膵外分 泌機能に及ぼす影響。日温気物医誌。1988; $51(2): 88-96$.

124）渡邊清剛, 樋口淳一, 小高ますみ, 吉井智 子, 今井賢治, 岩昌宏, 石丸圭荘, 篠原昭二, 畑幸樹, 咲田雅一. 消化器外科術後患者の膵 外分泌機能に対する鍼刺激の効果について. 明治鍼尒医学. 1991;9:53-9.

125）矢野 忠, 石崎直人, 廣 正基, 前田見太 郎，今川亮司，今久保伸二，岡本玄剛，山田 伸之, 山村義治, 中村直登. 胆囊収縮剤負荷 下における丘墟穴の胆囊形態に及ぼす効果. 明治鍼尒医学. 1994;15:39-46.

126）矢野 忠, 森 和, 芹澤勝助, 飯尾正宏. 東洋医学の基礎的検討. 体表刺激が内臓血行 に及ぼす影響について。理療の科学. 1977; 5(1):12-20.

127）山川 緑，篠原昭二，石丸圭荘，田和宗徳， 北出利勝, 岩 昌宏, 甲田久士, 咫 志宏, 工藤大作，渡邊勝之，畑 幸樹，鈴山博司， 咲田雅一，腸管運動に及ぼす鍼尒刺激の効果 に関する実験的検討。明治鍼尒医学. 1990;6: 89-95.

128）岩 昌宏, 篠原昭二, 石丸圭荘, 樋口淳一, 渡辺清剛, 吉井智子, 小高ますみ, 畑 幸 樹, 咲田雅一。ヒト腸蠕動に及ぼす鍼炎刺激 の効果（第2報）刺激部位の検討。明治鍼尒 医学. 1991;8:35-41.

129）岩 昌宏, 石丸圭荘, 篠原昭二, 渡辺清剛, 樋口淳一, 吉井智子, 小高ますみ, 今井賢 治, 畑 幸樹, 咲田雅一。ヒト腸蠕動に及ほ す鍼炎刺激の効果(第 3 報)，鍼通電刺激の検 討.明治鍼尒医学. 1991;9:17-22.

130）相田純久，党恵慶。電気銊の血清Gastrin濃 度に及ぼす影響。日温気物医誌。;55(3):1558.

131）和辻 直, 篠原昭二, 今井賢治, 岩 昌宏, 石丸圭荘, 佐々木定之, 咲田雅一. 消化管木 
ルモン，消化酵素に及ぼす鍼通電刺激の影響. 明治銊尒医学。1993;13:59-67.

132) Borjesson M, Pilhall M, Eliasson T, Norssell H, Mannheimer C, Rolny P.: Esophageal visceral pain sensitivity: effects of TENS and correlation with manometric findings. Dig Dis Sci. 1998; 43(8):1621-8.

133) Chang FY, Chey WY, Ouyang A. Effect of transcutaneous nerve stimulation on esophageal function in normal subjects--evidence for a somatovisceral reflex. Am J Chin Med. 1996; 24(2):185-92.

134）龍海燕．胃腸の蠕動障害に対する針多治療 効果の検討. 中西医結合. 1999;10(2):37-42.

135）疮海燕. 腸蠕動障害における銊尒の治療効 果と実験的研究. 中西医結合. 1999;10(4):427.

136) Smout AJ, van der Schee EJ, Grashuis JL. What is measured in electrogastrography?. Dig Dis Sci. 1980;25(3):179-87.

137）今井賢治, 岩 昌宏, 石丸圭荘, 和辻 直, 篠原昭二, 佐々木定之, 咲田雅一. 胃癌患者 およびその胃切除術後におけるElectrogastro- graphy (EGG). 京都府立医科大学雑誌. 1994;103(1):13-22.

138）今井賢治, 智原栄一, 石丸圭荘, 岩 昌宏, 池田和久，咲田雅一。ヒト胃電図におよぼす 硫酸アトロピンおよびネオスチグミンの影響. 日本自律神経学会雑誌. 1998;351(2):190-4.

139）今井賢治, 石丸圭荘, 池田和久, 岩 昌宏, 咲田雅一，腹部外科手術直後より翌朝までの Electrogastrography. 術後の異常波形に関する 検討. 医学のあゆみ. 1995;178(11):857-8.

140) Pfaffenbach B, Adamek RJ, Bartholomaus $C$, Wegener M.:Gastric dysrhythmias and delayed gastric emptying in patients with functional dyspepsia. Dig Dis Sci. 1997;42(10):2094-9.

141) Koch KL, Stern RM.: Functional disorders of the stomach.Semin Gastrointest Dis. 1996; 7(4):185-95. Review.

142）川喜田健司, 角谷英治, 野口榮太郎, 今井 賢治，七ミナー報告，ここまでわかった鍼炎 医学一基礎と臨床との交流一「内臟痛・消化 器機能 ·消化器症状への銊尒の効果」. 全日 本鍼尒学会雑誌. 2000;50(4):638-9.

\section{要旨}

「内臟痛と消化器疾患や各種消化器症状に対する銊尒治療」にテーマを絞り、その研究の現状について 基礎・臨床の両面から検討を加えた。今回、検討の対象としたものは、NIHの会議でも検討された関係分 野の欧文文献と、データベースや手作業によって網羅的に集められた和文文献、および一部の中文文献で ある。これまでの研究の歴史と研究の現状を簡潔に各テーマごとに網羅的にまとめた。「内臓痛に対する 鍼尒刺激の効果について」は、内臓痛に関する鍼尒の効果について、基礎医学的研究と臨床研究が紹介さ れ、さらに、直腸伸展刺激を用いた内臓痛モデル動物における銊の効果と視床内側下核との関連について の実験成績を総説した。「消化機能に対する鍼尒刺激の効果」については、唾液分泌、胃運動、胃酸分泌、 小腸運動に対する、鍼尒刺激の作用機序に関する研究について総説した。「消化器症状に対する銊尒治療 の効果」については、消化器疾患および消化器愁訴に対する銊尒治療の研究の歴史と現状を網羅し、臨床 研究における胃電図の有用性についても併せて総説した。

キーワード：内藏痛、消化機能、消化器症状、銊尒治療、システマテック・レビュー 